\title{
O direito comum das situações jurídicas patrimoniais
}

\section{For an unified law of obligations and property}

\section{Gabriel Rocha Furtado*}

\begin{abstract}
Nos direitos patrimoniais, quer sejam direitos reais, quer sejam de crédito, o objeto do direito é sempre uma utilidade que se encontra no mundo exterior.
\end{abstract}

San Tiago Dantas

\section{Resumo}

Classicamente, há uma dicotomia entre obrigações e direitos reais, que se daria por diferenças notáveis entre suas características e justificaria a construção de diferentes regimes jurídicos gerais, ainda que com algumas eventuais interseções. De outro modo, embora não seja nova, ainda é atual a discussão sobre uma possível unificação dos regimes jurídicos das obrigações e dos direitos reais em um único direito civil patrimonial comum. Este artigo busca demonstrar que as características historicamente associadas aos direitos reais para diferenciá-los das obrigações - (i) taxatividade e tipicidade, (ii) poder imediato, (iii) oponibilidade erga omnes, (iv) registro e publicidade, (v) preferência e (vi) direito de sequela - não são inaplicáveis em absoluto às obrigações. Há um caminho para a flexibilização das rígidas delimitações conceituais que sinaliza que, entre obrigações e direitos reais, não haveria diferenças qualitativas essenciais, mas, sobretudo, diferenças quantitativas na intensidade de seus efeitos em âmbito social. Por isso, conclui-se que seria possível, e até desejável, a unificação de ambos em um direito comum das situações jurídicas patrimoniais em geral.

Palavras-chave: Direito civil. Direito das obrigações. Direitos reais.

\section{Abstract}

Traditionally, there is an explicit divide between obligations and properties rights due to their well-known distinctive characteristics, which have been used to justify the existence of independent legal branches, notwithstanding some possible intersections. On the other hand, although not entirely a novelty, the discussion about a possible integration of both branches into a unified field of private law is still relevant. This article seeks to demonstrate that the characteristics historically associated to property law, in contrast to those of the law of obligations - i.e., (i) specificity and statutory definition; (ii) immediate disposability; (iii) erga omnes enforceability, (iv) public and official registry; (v) preference; and (vi) ownership protection - are not altogether inapplicable to obligations. In other words, it is possible to relax the rigid conceptual delimitations that encompass both branches, thus indicating that there may be no essential qualitative differences between property law and the law of obligations but rather quantitative variations regarding the intensity, from a social perspective, of their real-life applications. Therefore, one can affirm that it is viable, and even desirable, to coalesce both property law and the law of obligations into a unified and general branch of law concerning what is called juridical situation of property rights.

Keywords: Civil law. Law of obligations. Property law. 


\section{Introdução}

Este estudo objetiva fazer uma checagem a respeito da possibilidade de se construir um sistema interpretativo-aplicativo único ao direito civil patrimonial, isto é, verificar se entre direitos reais e obrigações existe um vão normativo intransponível ou se são possíveis pontes hermenêuticas que permitam uma definição conceitual nuclear que abranja as características fundamentais de todos os interesses patrimoniais da vida civil.

Esse exercício teórico é importante e pertinente, e tem como motivação específica estudos relacionados ao modelo negocial dos condomínios hoteleiros chamados de condohotéis. Tal modelo demanda a utilização das figuras mistas das obrigações com eficácia real para a redução dos riscos para investidores, com otimização da segurança jurídica para todas as partes envolvidas nas relações jurídicas em torno de si travadas. ${ }^{1}$

Objetiva-se compreender, assim, se tais espécies de figuras mistas, obrigações com eficácia real, estariam colocadas naquele núcleo conceitual de um direito comum patrimonial. Em caso negativo, se mais se aproximariam de direitos reais ou de obrigações; ou mesmo se essa tentativa de classificação, ou busca de sua natureza jurídica, seria despicienda por carência de utilização pragmática (MESQUITA, 1990, p. 32).

Procede-se, pois, à análise dos contornos conceituais das situações jurídicas patrimoniais e da possibilidade de criação de uma disciplina a elas comum.

\section{Situações reais e situações obrigacionais: distinção ou gradação?}

Professa Pontes de Miranda (2012c, p. 66) que "em sentido amplíssimo, propriedade é o domínio ou qualquer direito patrimonial". E continua: "tal conceito desborda o direito das coisas. O crédito é propriedade" (MIRANDA, 2012c, p. 66-67). De certo modo, está a falar sobre interessante debate jurídico que perdura em torno da questão atinente à existência ou não de uma distinção ontológica entre os direitos reais e as obrigações. Essa discussão inevitavelmente passa pelo estudo das características forjadoras das relações jurídicas, em geral, e das relações jurídicas reais e obrigacionais, em específico.

Além de outras características que têm sido apontadas por parte da doutrina como elementos distintivos, enquanto às obrigações tem sido relacionado um poder mediato sobre um bem, a depender da prestação de uma pessoa devedora, aos direitos reais tem sido associado um poder imediato sobre uma coisa (DANTAS, 1979, p. 225). Entre os direitos reais, a propriedade seria a espécie a conferir à pessoa que a titulariza a mais ampla gama de poderes - chegando-se a se dizer, no passado, que o domínio iria do céu ao inferno. ${ }^{2}$

Nesse liame visceral muito se baseou a teoria realista (ou clássica) para afirmar que as relações jurídicas reais são travadas entre a pessoa que titulariza determinado direito real e a coisa titularizada (PENTEADO, 2014, p. 72-73). Essa ideia foi sucedida pela teoria personalista (ou moderna), a definir a relação jurídica real como travada entre a pessoa titular de certo direito real e toda a universalidade passiva de pessoas não titulares (PENTEADO, 2014, p. 77). Defendeu-se, pois, a existência de uma obrigação passiva universal nas relações jurídicas reais (MIRANDA, 2012c, p. 57).

Embora divergentes, tais teorias apresentam os fundamentos das duas características que, de forma mais marcante, têm sido associadas aos direitos reais. A primeira, o poder imediato sobre a coisa, em uma dimensão interna voltada às possibilidades de aproveitamento econômico de determinado bem jurídico pela pessoa titular de um direito real a ele ligado. A segunda, relacionada a uma oponibilidade erga omnes, em uma dimensão externa voltada às relações jurídicas travadas entre as pessoas titulares de referidos direitos reais e as demais, não titulares (RENTERIA, 2016, p. 10). ${ }^{3}$

Doutrina mais recente, contudo, tem se dedicado a criticar os fundamentos daquelas duas características centrais, e, em ato contínuo, os de outras costumeiramente associadas aos direitos reais. Isso tem levado a uma aproximação qualitativa entre os direitos reais e as obrigações - doravante tratados como situações

Cf. Gustavo Tepedino e Gabriel Rocha Furtado (2015, p. 143-162).

Cf., em um viés crítico a esse entendimento, Carlo Francesco Gabba (1909, p. 112-132). Em crítica a uma acepção individualista da propriedade, ver Pietro Barcellona (1988).

Em complemento, ver Luciano de Camargo Penteado (2014, p. 77). 
jurídicas reais e situações jurídicas obrigacionais, por serem expressões que melhor exprimem a complexidade dos direitos, em sentido largo, nas relações jurídicas. ${ }^{4}$

O cotejo teórico entre as situações jurídicas reais e as situações jurídicas obrigacionais busca aferir se há uma distinção qualitativa ou mera gradação quantitativa relativa ao grau de abrangência social de suas eficácias. Para tanto, fazse presente a incontornável necessidade de se perscrutar as substâncias de tais situações jurídicas, a fim de que o comparativo se faça possível para maior ou menor aproximação, ou distanciamento.

A questão central seria: há alguma característica exclusiva, independente e permanente das situações jurídicas reais em relação às obrigacionais $?^{5} \mathrm{~A}$ resposta a essa pergunta é fundamental para uma precisa conceituação e eventual construção de uma disciplina jurídica única a todas as situações patrimoniais.

Classicamente, a doutrina costumava fazer uma cisão absoluta. Teixeira de Freitas afirmou, em conhecida passagem na introdução de sua Consolidação das Leis Civis, que "na distinção dos direitos reais, e dos direitos pessoais repousa todo o sistema do Direito Civil" (FREITAS, 2003, p. LXII). Em seu Esboço de Código Civil do Império, contratado pelo Decreto $n .{ }^{\circ} 2.337 / 1859,{ }^{6}$ previu normativamente tal distinção, especialmente nos artigos 18 e $19 .{ }^{7}$ De certa forma, essa cisão entre as duas categorias tem sido seguida pelos cursos de direito civil mais tradicionais da doutrina brasileira, ainda que sem resumir todo o sistema civilista a ela. ${ }^{8}$

Mais recentemente, ao contrário, por conta do processo de (re)personalização do direito civil, que tem por desiderato (re)colocar a pessoa no centro das relações civis (PERLINGIERI, 2002, p. 33) ${ }^{9}-$ e que foi catalisado com a promulgação da Constituição da República de 1988 -, a mais importante classificação é externa à categorização entre situações jurídicas obrigacionais e reais. Dá-se, assim, entre as situações jurídicas existenciais e patrimoniais, conforme professado por Gustavo Tepedino (2006, p. 137):

\begin{abstract}
A classificação que deve ser estabelecida, para a interpretação e aplicação das normas jurídicas, é a que estrema as relações jurídicas patrimoniais, constituídas por situações jurídicas economicamente mensuráveis, e as relações jurídicas não patrimoniais, formadas por situações jurídicas insuscetíveis de avaliação econômica, caracterizadas por interesses não patrimoniais. A distinção assume posição proeminente na medida em que diversos são os valores que informam ambas as categorias de situações jurídicas. A Constituição Federal considera a dignidade da pessoa humana como fundamento da República (art. $1^{\circ}$, C.F.), alçando as situações jurídicas não patrimoniais ou existenciais ao vértice da hierarquia dos interesses juridicamente tutelados. Para expressar a tábua axiológica (conjunto de valores estabelecidos) no direito positivo brasileiro, pode-se dizer, em linguagem comum, que, para o constituinte, o ser é mais importante que o ter. (Grifou-se).
\end{abstract}

Não obstante, há um universo peculiar às relações jurídicas patrimoniais protegidas pelo ordenamento constitucional brasileiro e também demandante de estudo próprio a si. Isso passa inevitavelmente pela reflexão a respeito das funções e das características das situações jurídicas patrimoniais no direito brasileiro. ${ }^{10}$ No que é mais específico ao presente estudo, há de se analisar as peculiaridades das situações jurídicas definidas como reais pela legislação pátria. ${ }^{11}$

\title{
3 Princípios gerais das situações reais e sua mitigação contemporânea
}

Há em curso um processo contemporâneo de revisão e mitigação das características principiológicas das situações jurídicas reais, a fim de que o processo de suas qualificações jurídicas como tais não seja

Cf. Pietro Perlingieri (2008, p. 677-678) e José de Oliveira Ascensão (2010, p. 11-12).

Sobre a natureza dos objetos à luz da teoria do conhecimento, cf. Johannes Hessen (1999, p. 146-147).

"Approva o contracto celebrado com o Bacharel Augusto Teixeira de Freitas para a reducção do projecto do Codigo Civil do Imperio". Disponível em: http://www2.camara.leg.br/legin/fed/decret/1824-1899/decreto-2337-11-janeiro-1859-557246-publicacaooriginal-77587-pe.html. Acesso em: 16 maio 2017.

7 "Art. 18. Os direitos, que o presente Código regula, são considerados em relação ao seu objeto, e distinguidos em direitos pessoais, e diretos reais. Os direitos pessoais são distintamente considerados nas relações de família, e nas relações civis. / Art. 19. São direitos pessoais os que têm por objeto imediato as pessoas, pôsto que mediatamente possam ter por objeto as coisas. São direitos reais os que têm por objeto imediato as coisas, pôsto que mediatamente tenham por objeto as pessoas" (FREITAS, 1952, p. 22).

8 Cf., e.g., Lafayette Rodrigues Pereira (1956, p. 19-21); Caio Mário da Silva Pereira (2011a, p. 37); Orlando Gomes (2012, p. 9-17); Paulo Nader (2005, p. 11-13); Sílvio de Salvo Venosa (2004b, p. 27-28). Em sentido diverso, ver Astolpho Rezende (2000, p. 30-31).

Para uma leitura funcional dessa despatrimonialização e de seus efeitos no direto civil brasileiro, cf. Luiz Edson Fachin (2006).

10 Sobre as vantagens de uma leitura funcional a uma estrutural dos institutos jurídicos, cf. Norberto Bobbio (2007).

11 Aproveita-se, aqui, honesto alerta feito por Luiz Edson Fachin (2006, p. 22): "Tem o trabalho campo epistemológico definido: o Direito e a experiência jurídica no Brasil. Não desconhece a contribuição estrangeira, sempre valiosa, que aqui somente comparece, sob essa fronteira proposital, quantum satis". 
definido por esquemas conceituais abstratos, mas sim levando em conta precipuamente os seus conteúdos e as suas funções em concreto (COMPORTI, 1977, p. 5). Afinal, os institutos jurídicos devem servir à realidade socioeconômica, e não o inverso (ASCENSÃO, 2005, p. 591).

As características principiológicas usualmente associadas às situações jurídicas reais são: (i) taxatividade e tipicidade, (ii) poder imediato, (iii) oponibilidade erga omnes, (iv) registro e publicidade, (v) preferência e (vi) direito de sequela. A análise de cada uma partirá de suas tradicionais definições conceituais, apresentando-se a crítica doutrinária que tem sido feita e que tem levado aos seus abrandamentos, isto é, a uma flexibilização de seus contornos conceituais, que tem permitido maior fluidez e intercâmbio dos regimes jurídicos originariamente afeitos, de maneira rígida e estanque, às situações jurídicas reais e às situações jurídicas obrigacionais.

\subsection{Taxatividade e tipicidade}

Há estimulante discussão doutrinária a respeito de incidência dos princípios da taxatividade e da tipicidade no Brasil. De acordo com a doutrina brasileira de escol, taxatividade se refere ao fechamento, pela lei, do número de espécies de figuras reais admitidas nas relações civis, enquanto tipicidade se refere ao regime jurídico daquelas espécies, isto é, aos seus conteúdos (TEPEDINO, 2012a, p. 52-53). ${ }^{12}$

Desse modo, defender que o direito brasileiro adotaria a taxatividade e a tipicidade estritas de suas figuras reais significaria dizer, respectivamente, que o sistema adotado seria o de numerus clausus e que os regimes jurídicos das espécies previstas em lei seriam cogentes e não ampliáveis. Isso impossibilitaria a criação de novas figuras reais e/ou de novos conteúdos, para mais ou para menos, em relação ao regime jurídico legal, pela autonomia privada (VENOSA, 2005, p. 26).

De fato, não é tarefa hercúlea enumerar as espécies e os regimes jurídicos das situações jurídicas reais no direito civil brasileiro; estão traçados no Título II do Livro III da Parte Especial do Código Civil (Lei Federal n. ${ }^{\circ}$ 10.406/2002) e na legislação especial. Para além do rol previsto no art. 1.225 do Código Civil, ${ }^{13}$ há, e.g., (i) a concessão de uso do espaço aéreo sobre a superfície de terrenos públicos ou particulares (Decreto-lei n. ${ }^{\circ}$ 271/1967), (ii) a propriedade fiduciária imobiliária (Lei Federal n. ${ }^{\circ}$ 9.514/1997), (iii) o uso da derivação de águas (Código de Águas), ${ }^{14}$ o direito de superfície urbana (Lei Federal n. ${ }^{\circ}$ 10.257/2001) e a patente (Lei Federal n. ${ }^{\circ}$ 9.279/1996). ${ }^{15}$

A questão, todavia, não é tão simples quanto possa parecer em um primeiro momento. As divergências têm início já quanto a se saber se o sistema brasileiro adota ou não o princípio da taxatividade, isto é, se vigora no Brasil um regime de numerus clausus ou numerus apertus de situações jurídicas reais. Embora não haja regra explícita sobre a impossibilidade de a autonomia privada criar novas espécies de direitos reais, é esse o entendimento prevalecente na doutrina brasileira. ${ }^{16} \mathrm{~A}$ controvérsia é antiga e já se fazia presente à época da elaboração do Esboço de Código Civil por Teixeira de Freitas, concluído em 1864 (WALD, 2009, p. 24). Nesse constava Freitas, (1952, p. 1093-1094):

Art. 3.703. A nenhum direito se atribuirá o caráter de direito real (art. 19) fora das espécies designadas neste Título, e do modo pelo qual neste Livro regula-se cada uma delas. / Art. 3.704. Sôbre coisas próprias são unicamente direitos reais: $10^{\circ} \mathrm{O}$ domínio. $2 .^{\circ} \mathrm{O}$ condomínio. / Art. 3.705. Sôbre coisas alheias são unicamente direitos reais: $1 .^{\circ} \mathrm{A}$ enfiteuse. $2 .^{\circ} \mathrm{O}$ usufruto. $3 .^{\circ} \mathrm{O}$ uso, e a habitação. $4 .^{\circ}$ As servidões ativas. $5 .^{\circ} \mathrm{O}$ direito de hipoteca. $6 .^{\circ} \mathrm{A}$ anticrese. $7 .^{\circ} \mathrm{O}$ penhor. / Art. Julgar-se-á nãoescrita, para valer somente como constitutiva de direitos pessoais (art. 19), se por tal puder valer, tôda estipulação, ou disposição de última vontade, que constitua outros direitos reais, ou que modifique os permitidos ao contrário das disposições que os regulam.

Cf. também André Osório Gondinho (2001, p. 15-16).

"Art. 1.225. São direitos reais: I - a propriedade; II - a superfície; III - as servidões; IV - o usufruto; V - o uso; VI - a habitação; VII - o direito do promitente comprador do imóvel; VIII - o penhor; IX - a hipoteca; X - a anticrese; XI - a concessão de uso especial para fins de moradia; XII - a concessão de direito real de uso; XIII - a laje".

14 Decreto $n^{\circ} 24.643 / 1934$, art. 50: "O uso da derivação é real; alienando-se o prédio ou o engenho a que ela serve passa o mesmo ao novo proprietário". Não se confunde e, também por isso, não foi derrogado pelo disposto nos artigos 1.288 ao 1.296 do Código Civil, que tratam de relações de vizinhança.

15 Cf. Pedro Marcos Nunes Barbosa (2016, p. 58)

16 Na doutrina, entre outros, cf. Lafayette Rodrigues Pereira (1956, p. 22); Clóvis Beviláqua (1946, p. 304); Francisco Cavalcanti Ponte de Miranda (2012a, p. 98-99); Orlando Gomes (2012, p. 21-22); Caio Mário da Silva Pereira (2009, p. 5). 
Havia, portanto, vedação expressa - "unicamente" - à criação de outras espécies reais que não as previstas no próprio código. Como é sabido pela história, o Esboço não vingou no Brasil, embora tenha influenciado o jurista Vélez Sarsfield na elaboração do Código Civil argentino de 1869 - Ley 340, de 25/09/1869 - (WALD, 1999, p. 257) ${ }^{17}$ recentemente revogado pela Ley 26.994 , de 01/10/2014. ${ }^{18}$

Por seu turno, o Código Civil brasileiro de 1916, oriundo de projeto original de Clóvis Beviláqua, ${ }^{19}$ não trazia vedação expressa à criação de outras figuras reais que não as enumeradas por seu art. 674 : "São direitos reais, além da propriedade: I - A emfiteuse; II - As servidões; III - O usofruto; IV - O uso; V - A habitação; VI - As rendas expressamente constituídas sobre imóveis; VII - O penhor; VIII - A anticrise; IX - A hipoteca". A redação que constava no manuscrito, após aparente correção, era "somente se consideram direitos reais, além da propriedade". A supressão do vocábulo "somente" fez surgir discussão doutrinária a respeito de ter sido adotado um rol taxativo ou não. ${ }^{20}$

Figura 1 - Manuscrito de Clóvis Beviláqua.

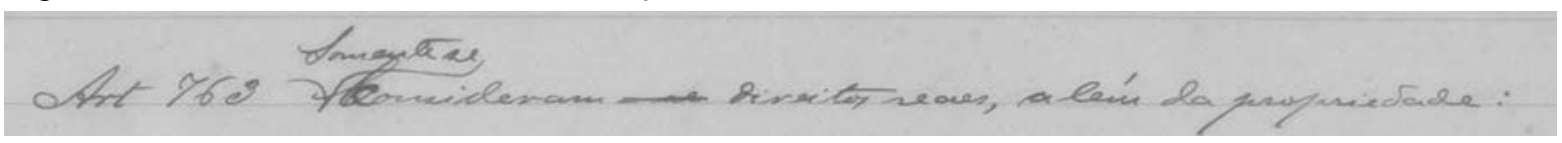

Fonte: Original do Projeto do Código Civil elaborado por Clóvis Beviláqua. ${ }^{21}$

Da mesma forma, o Código Civil brasileiro de 2002 - instituído pela Lei Federal n. ${ }^{\circ}$ 10.406/2002 - não traz vedação expressa à criação de novas espécies reais pela autonomia privada. Também não há na legislação constitucional e na legislação extravagante. ${ }^{22}$ Todavia há na sua exposição de motivos pelo menos duas passagens que são bons indícios de que o intuito parlamentar, que a rigor representa o concreto exercício democrático do poder do povo, ${ }^{23}$ foi o de estabelecer na legislação civil pátria o princípio da taxatividade das situações jurídicas reais (REALE, 2005, p. 49-51).

Por essa leitura, no Brasil apenas deveriam ser considerados direitos reais em sentido estrito os que venham a ser reconhecidos como tal pela lei. Não vigoraria aqui, pois, o regime de numerus apertus quanto às situações jurídicas reais - como o há, por exemplo, na Espanha, ainda que com limitações. (DÍEZ-PICAZO, 2008, p. 131-151). Há julgados de tribunais brasileiros que acatam esse entendimento ${ }^{24}$ Contudo, conforme respeitável doutrina:

O sistema do numerus clausus não se apresenta ontologicamente vinculado à noção de direitos reais; ao revés, relaciona-se à política legislativa. Com efeito, o problema da segurança jurídica que se pretende sanar com eficácia erga omnes dos direitos reais resolve-se com o sistema de registro; inserindo-se, portanto, no espectro de incidência do princípio da publicidade, o que, em última análise, poderia tornar dispensável a taxatividade. (TEPEDINO; BARBOZA; MORAES, 2011, p. 489).

17 O inteiro teor do referido código está disponível em: http://servicios.infoleg.gob.ar/infoleglnternet/verNorma.do?id=109481. Acesso em: 18 maio 2017. Dispunha o seu art. 2.502: "Los derechos reales sólo pueden ser creados por la ley. Todo contrato o disposición de última voluntad que constituyese otros derechos reales, o modificase los que por este Código se reconocen, valdrá sólo como constitución de derechos personales, si como tal pudiese valer".

18 "ARTICULO $4^{\circ}$ - Deróganse el Código Civil, aprobado por la ley 340, y el Código de Comercio, aprobado por las leyes Nros. 15 y 2.637 , excepto los artículos 891, 892, 907, 919, 926, 984 a 996, 999 a 1003 y 1006 a 1017/5, que se incorporan como artículos 631 a 678 de la ley 20.094 , facultándose al Poder Ejecutivo nacional a renumerar los artículos de la citada ley en virtud de la incorporación de las normas precedentes". O inteiro teor do referido código está disponível em: http://servicios.infoleg.gob.ar/infoleglnternet/verNorma.do?id=235975. Acesso em: 18 maio 2017.

19 O inteiro teor do manuscrito original do Projecto do Código Civil Brasileiro está disponível em: http://bdjur.tjce.jus.br/jspui/handle/123456789/196. Acesso em: 18 maio 2017.

20 Washington de Barros Monteiro defendia não ser rol taxativo o do art. 674 do Código Civil de 1916 (1991, p. 12).

21 Disponível em: http://bdjur.tjce.jus.br/jspui/handle/123456789/196. Acesso em: 17 jul. 2020.

22 Inexiste na lei civil brasileira dispositivo semelhante ao constante no art. $1306^{\circ}$ do Código Civil português, que preceitua: "1306. ${ }^{\circ}$ («Numerus clausus») 1. Não é permitida a constituição, com caráter real, de restrições ao direito de propriedade ou de figuras parcelares deste direito senão nos casos previstos na lei; toda a restrição resultante de negócio jurídico, que não esteja nestas condições, tem natureza obrigacional".

23 Constituição da República, art. $1^{\circ}$, parágrafo único: "Todo o poder emana do povo, que o exerce por meio de representantes eleitos ou diretamente, nos termos desta Constituição".

24 Ilustrativamente, do Tribunal de Justiça de São Paulo: TJSP; Agravo de Instrumento 0053750-44.2005.8.26.0000; Relator (a): Oséas Davi Viana; Órgão Julgador: 23a Câmara de Direito Privado; Foro Central Cível - 37ª VC; Data do Julgamento: 22/02/2006; Data de Registro: 14/03/2006. E do Tribunal de Justiça de Minas Gerais: TJMG - Apelação Cível 1.0313.04.127293-8/001, Relator(a): Des.(a) Marcelo Rodrigues, 11ª CÂMARA CíVEL, julgamento em 04/07/2007, publicação da súmula em 25/07/2007. 
Já quanto ao princípio da tipicidade, a doutrina se divide entre ela ser fechada ou aberta. Referindose ao conteúdo das figuras reais, a divergência se dá quanto ao entendimento de o regime legal previsto em lei ser cogente e inflexível - daí se falar em uma tipicidade fechada - ou, ao contrário, ser ele poroso e flexível, a admitir modulações negociais pelos particulares - daí se falar, nesse caso, em uma tipicidade aberta (TEPEDINO; BARBOZA; MORAES, 2011, p. 489).

Indicativo dado pela jurisprudência nacional de que possivelmente prevaleça no ordenamento jurídico brasileiro o segundo entendimento, afeito a uma configuração aberta da tipicidade das situações jurídicas reais criadas pela lei, foi o acórdão proferido pelo Superior Tribunal de Justiça no julgamento do Recurso Especial n. ${ }^{0} 1.546 .165 / S P .{ }^{25}$ A questão envolvia a qualificação jurídica de uma multipropriedade imobiliária. (TEPEDINO, 1993). Consignou-se no voto condutor que, embora houvesse compreensão de que ela teria feição obrigacional, uma vez que seu regime jurídico era resultado de modulações contratuais, o melhor entendimento seria o de que ela estaria acobertada pela lógica jurídica atinente às figuras reais. Seria, possivelmente, uma forma atípica do direito de propriedade (TEPEDINO, 1993, p. 18-19).

Assim, caminha-se para o prevalecimento, agora com aceitação pelo Tribunal competente, da uniformização da legislação nacional infraconstitucional ${ }^{26}$ e do entendimento de que no sistema jurídico de situações reais vigeriam os princípios da taxatividade e da tipicidade aberta, isto é, apenas a legislação poderia estipular quais seriam as figuras reais admitidas no direito brasileiro, mas os particulares poderiam modular os conteúdos e efeitos genericamente traçados pela lei. Não de forma absolutamente livre, mas pautada e funcionalizada "aos princípios e valores do sistema civil-constitucional" (TEPEDINO; BARBOZA; MORAES, 2011, p. 490).

Destarte, há em curso uma mitigação do antes rígido regime jurídico real no Brasil (CARVALHO, 2012, p. 183). ${ }^{27}$ Isso faz com que haja uma aproximação sua com o regime jurídico obrigacional, no sentido de que se abre espaço - ou se dá porosidade - a fim de que haja maior presença da autonomia privada também na criação, na modificação, no exercício e na alienação das situações jurídicas reais.

\subsection{Poder imediato}

Ao poder imediato sobre um "bem" ou uma "coisa" tem sido historicamente associada a ideia de que existiria um vínculo jurídico concreto e direto entre o sujeito titular e o "bem". Prefere-se aqui a expressão "bem" em vez de "coisa" por se entender que aquela é tecnicamente mais adequada às situações jurídicas reais, uma vez que engloba também os bens imateriais. O conceito de coisa, como se sabe, melhor se adequa aos bens materiais, corporificados.

Conforme aquele entendimento, seria este um dos grandes distintivos, senão o maior, entre as situações jurídicas reais e as creditícias: "o direito real se caracterizaria por atribuir ao titular poder imediato ser a res, ao passo que o direito pessoal consubstanciaria o poder sobre o ato do devedor" (RENTERIA, 2016, p. 7-8). Afirma San Tiago Dantas (1981, p. 15): "no direito real, o dever jurídico a ele correspondente adere à coisa e a acompanha, sendo, como se costuma dizer, ambulatório. A ambulatoriedade do dever jurídico é inerente ao direito real".

A consequência efetiva dessa ambulatoriedade seria o direito de sequela. ${ }^{28}$ Por se ligar diretamente ao bem, uma pretensão real poderia ser dirigida a qualquer pessoa que momentaneamente o estivesse possuindo ou apropriando. ${ }^{29}$ Daí, no primeiro caso, das situações reais, o titular do direito violado poderia buscar o bem onde e com quem estivesse, ao passo que, no segundo, das situações obrigacionais, caberia apenas uma pretensão contra a pessoa devedora para coagi-la a prestar o devido (COMPORTI, 1977, p. 77). Haveria, nesse caso, pois, uma relação mediata com o bem perseguido. Nessa visão, conforme

REsp 1.546.165/SP, Rel. Ministro Ricardo Villas Bôas Cueva, Rel. p/ Acórdão Ministro João Otávio de Noronha, Terceira Turma, julgado em 26/04/2016, DJe 06/09/2016.

26 Constituição da República, art. 105, III.

27 Em posição diversa, favorável à manutenção do princípio do numerus clausus e do da tipicidade fechada (ou estrita) às situações reais, cf. Luciano de Camargo Penteado (2014, p. 113-114).

Cf. Orlando Gomes (2012, p. 20) e San Tiago Dantas (1981, p. 15-16).

29 A respeito de possível diferença conceitual entre propriedade e domínio, cf. Ricardo Aronne (1999). 
Darcy Bessone (1988, p. 4), enquanto nas situações reais haveria um poder sobre o bem ("jus in re"), nas obrigacionais haveria uma tendência a ele ("jus ad rem"). Quanto a isso, aduz Pietro Perlingieri (2008, p. 897):

A noção de situação real deriva da relação, não só de dependência, mas também de inerência, entre o direito e o seu objeto, entre a situação e o bem: a situação real grava sobre uma res determinada, específica. A situação creditória, não tendo uma relação de inerência ou de imanência com uma res, se realiza mediante o adimplemento e a obtenção de um resultado. Característica de destaque é o comportamento devido: a prestação. Na situação dita real, a utilidade, o resultado útil para o titular, se identifica na imediatidade entre situação e utilidade oferecida pela res, sem que, normalmente, seja necessária a intervenção por parte de um terceiro. Na situação dita creditória o interesse do titular se realiza exclusivamente mediante a atividade, a intermediação do sujeito obrigado, intermediação que, quando presente nas situações reais, assume um papel complementar.

Como se percebe, o fundamento teórico dessa característica está ligado à teoria realista, que pressupunha existir uma relação entre pessoa e bem. Como corolário da objeção a ela feita pela teoria personalista, de que as relações jurídicas seriam travadas entre pessoas e não entre pessoas e bens, colocou-se em xeque também o entendimento de que existiria um poder imediato da pessoa titular sobre um bem como caráter distintivo das situações reais e obrigacionais. Isso tanto por alegadamente existirem espécies reais que não conferem tal poder imediato, quanto por este poder vir a ser verificado também em situações jurídicas obrigacionais. Conforme apontado por Pablo Renteria (2016, p. 18), esse questionamento não é exatamente novo, pois, ainda na década de 1940, já havia sido feito por Michele Giorgianni (1940, p. 106-108) na Itália:

Come è noto infatti, la dottrina dominante pone una profonda differenza di struttura e di contenuto tra i diritti che hanno come oggetto il godimento della cosa altrui a seconda che essi appartengano alla categoria dei diritti reali o a quella dei diritti obbligatori (o personali), in base alla profonda diversità, nell'una o nell'altra ipotesi, degli strumenti predisposti dall'ordinamento giuridico per il raggiungimento del bene tutelato (godimento della cosa altrui). Ora, crediamo che questa dottrina tradizionale, la quale è stata del resto da più parti soggetta a critiche, possa essere riveduta da un punto di vista completamente nuovo. [...] A nostro avviso, la questione deve essere invece affrontata e risolta totalitariamente. [...] il rapporto di godimento della cosa altrui può essere studiato senza alcun riferimento alla fonte dal quale esso promana concretamente: crediamo perciò possibile studiare il contenuto e la struttura di esso da un punto di vista unitario, salvo poi a vedere se la diversità della fonte influisca in qualche atteggiamento concreto nelle singole ipotese.

Se, em algumas espécies de situações reais, há ordinariamente uma forte aproximação naturalística entre pessoa titular e bem objeto de sua titularidade - a propriedade sendo o mais robusto exemplo em que há tal poder imediato -, em outras não se verifica essa aproximação. Exemplos das últimas são, ilustrativa e não exaustivamente, (i) as servidões negativas, (ii) o penhor e (iii) a hipoteca.

Nas servidões negativas, ${ }^{30}$ que impõem ao titular do prédio serviente um dever de abstenção em relação a algum ato que normalmente poderia ser realizado - como uma construção, exemplificativamente -, não há um tangível aproveitamento econômico do bem dominado. A vantagem trazida ao titular do prédio dominante não deriva propriamente de alguma característica concreta, ou de alguma potencialidade material, do bem sobre o qual a servidão incide; provém direta e exclusivamente, sim, de um comportamento cooperativo do vizinho, de não agir. ${ }^{31}$

Daí não se verificar, nesse caso, uma peculiaridade que justifique uma qualificação jurídica substancialmente distinta em relação, especificamente, às obrigações de não fazer. Em um caso e no outro, a pretensão material é adimplida por um comportamento do titular do bem no qual incidente a servidão negativa. No caso, um comportamento omissivo. ${ }^{32}$

Quanto ao penhor, ${ }^{33} \mathrm{em}$ que pese haver, para a maioria de suas formas, a transferência da posse do bem ao credor, não perde o devedor a faculdade de disposição (RENTERIA, 2016, p. 23-24). Mas, mais importante

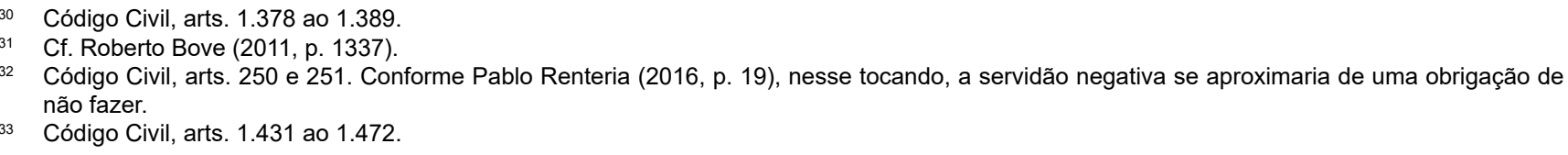


que isso - pois, a rigor, também vem a ocorrer com a anticrese -, o credor tem satisfeita a sua pretensão contra o devedor por um comportamento deste, e não por extrair diretamente utilidades do bem objeto do penhor.

Desse modo, seu interesse econômico é realizado mediatamente através do bem, que serve apenas de garantia para que aquele interesse seja alcançado imediatamente pelo comportamento do devedor que indicou o bem para penhor. Isso se torna ainda mais característico nas espécies de penhor em que não há a transferência da posse do bem para o credor, como, e.g., no penhor rural. ${ }^{34}$ Finalmente, considerandose que o credor não poderá realizar diretamente o seu crédito por direta apropriação do bem, no caso de inadimplemento do devedor, a conclusão a respeito da inexistência de um poder imediato (como classicamente concebido) no caso do penhor se torna de difícil refutação. ${ }^{35}$

Já na hipoteca, ${ }^{36}$ além de não haver a transferência da posse do bem para o credor e de sua pretensão material se realizar por um comportamento do devedor, não há a possibilidade de o credor hipotecário realizar o seu crédito diretamente sobre o bem em caso de inadimplemento. ${ }^{37}$ Assim, não há, nessa hipótese, aproveitamento direto do bem pelo titular da situação real de garantia. Ao argumento de que o poder de excussão do bem seria uma forma de manifestação de poder imediato sobre o bem, objeta-se que é ela, sim, uma manifestação do poder estatal de coerção. Entender o contrário acarretaria o reconhecimento forçoso também do caráter real de um crédito quirografário ou a existência de um poder imediato sobre um bem, no caso de uma execução específica, por exemplo, de uma obrigação de dar coisa certa. ${ }^{38}$ Sintetiza Pablo Renteria (2016, p. 20):

A qualquer credor se reconhece o direito subjetivo público de exigir do Judiciário a tutela do seu direito. A penhora do imóvel hipotecado e a sua posterior alienação judicial são, contudo, atos estatais ordenados pelo juiz. Em definitivo, a agressão do bem hipotecado é um poder do Estado, e não do credor.

Ademais, nem sempre cabe o direito de reaver um bem, ou uma execução específica, nas situações jurídicas reais. Exemplo característico em que não ocorrem é o da alienação a "non domino" de bem móvel a terceiro de boa-fé em oferta ao público, leilão ou estabelecimento comercial "em circunstâncias tais que, ao adquirente de boa-fé, como a qualquer pessoa, o alienante se afigurar dono". ${ }^{39}$ Nesse caso, diferentemente do que pode ocorrer na aquisição de bem imóvel por terceiro de boa-fé com base em registro posteriormente cancelado, ${ }^{40}$ ao proprietário lesado caberia apenas execução pelo equivalente contra o alienante a "non domino" ou terceiro responsável pelo dano. Enfim, é uma hipótese ilustrativa de não ser o poder imediato sobre o bem uma característica imanente das situações jurídicas reais.

Por outro flanco, verifica-se que também há poder imediato sobre bens em algumas situações jurídicas obrigacionais. É o caso, exemplificativamente, das obrigações oriundas de contratos de locação. ${ }^{41}$ Ao locador é reconhecida uma posição jurídica que lhe permite um aproveitamento econômico direto sobre o bem locado (GIORGIANNI, 1940, p. 52). De acordo com a lei, "na locação de coisas, uma das partes se obriga a ceder à outra, por tempo determinado ou não, o uso e gozo de coisa não fungível, mediante certa retribuição" ${ }^{42}$ Semelhante situação ocorre também nos contratos de empréstimo. ${ }^{43}$

\footnotetext{
Código Civil, arts. 1.438 ao 1.446. Cf. Orlando Gomes (2012, p. 369).

Código Civil, art. 1.428. "A figura do pacto comissório traduz-se, portanto, na proibição de celebração de negócio jurídico que autorize o credor a apropriar-se da coisa dada em garantia, em caso de inadimplência do devedor, sem antes proceder à execução judicial do débito garantido" (REsp 954.903/RS, Rel. ministro Marco Buzzi, Quarta Turma, julgado em 11/12/2012, DJe 01/02/2013). A adjudicação no caso da expropriação de bens (Código de Processo Civil, arts. 876 ao 878) não representa a aceitação do pacto comissório no Brasil, pois há, nesse caso, execução judicial do débito garantido. Quanto ao debate sobre o cabimento do pacto marciano no Brasil, cf. Carlo Edison do Rêgo Monteiro Filho (2017). Código Civil, arts. 1.473 ao 1.505

Como há, por exemplo, na anticrese (Código Civil, arts. 1.506 ao 1.510).

Código de Processo Civil, arts. 806 ao 810.

"Código Civil, art. 1.268. Feita por quem não seja proprietário, a tradição não aliena a propriedade, exceto se a coisa, oferecida ao público, em leilão ou estabelecimento comercial, for transferida em circunstâncias tais que, ao adquirente de boa-fé, como a qualquer pessoa, o alienante se afigurar dono".

40 "Código Civil, art. 1.247. Se o teor do registro não exprimir a verdade, poderá o interessado reclamar que se retifique ou anule. / Parágrafo único. Cancelado o registro, poderá o proprietário reivindicar o imóvel, independentemente da boa-fé ou do título do terceiro adquirente".

Código Civil, arts. 565 ao 578, e Lei Federal n. ${ }^{\circ} 8.245 / 1991$

Código Civil, art. 565. Em complemento, cf. art. 22, I e II, da Lei Federal n. ${ }^{\circ}$ 8.245/1991.

Código Civil, arts. 579 ao 592.
} 
Por isso, se conclui que "não é relevante, para a qualificação da situação como real ou creditória, que ela tenha na res o ponto de referência objetivo" (PERLINGIERI, 2008, p. 899-900). ${ }^{44}$

\subsection{Oponibilidade erga omnes}

A doutrina preponderante defende que as situações jurídicas reais são absolutas, pois os deveres jurídicos irradiados a partir dela afeta a toda a universalidade de pessoas não titulares (DANTAS, 1981, p. 11). Daí se falar que elas têm, caracteristicamente, uma oponibilidade erga omnes. De acordo com San Tiago Dantas (1981, p. 12-13),

[s]e se diz que o direito real prevalece erga omnes, quer-se com isto exprimir, apenas, que o dever jurídico a ele correspondente não recai sobre uma determinada pessoa; recai sobre todas as pessoas. A sociedade é constituída de uma multidão de devedores; apartado dessa multidão encontra-se apenas o titular do direito real. De tal sorte, que se encontra de um lado da relação jurídica esse titular e, de outro, aquela multidão de não titulares.

Embora tal caracterização tenha derivado da teoria personalista (COMPORTI, 1977, p. 14), ${ }^{45}$ que veio a se contrapor à realista, de certo modo, é uma consequência da acepção de que haveria um poder imediato do titular com o bem. Isso ocorre porque, uma vez existente esse poder imediato, caberia a toda a universalidade de não titulares respeitar as faculdades de aproveitamento oriundas e cabíveis ao titular. Por isso, a fim de exigir o respeito dos demais, o titular da situação jurídica real necessitaria provar apenas a sua titularidade e, em sendo o caso, a sua violação (PENTEADO, 2014, p. 120).

Apresentou-se, então, a ideia de uma obrigação passiva universal, a justificar a defendida oponibilidade erga omnes das situações jurídicas reais (COMPORTI, 1977, p. 14). De acordo com esse entendimento, uma relação jurídica estabelecida com uma situação jurídica real geraria automaticamente um vínculo jurídico entre seu titular e toda a universalidade de pessoas não titulares, que estariam obrigadas a um não fazer. No caso, a não agir contra o direto de aproveitamento econômico do bem por parte do titular da situação jurídica real, sem embaraços (MAIA, 2013, p. 182).

Ocorre que, de acordo com a crítica, haveria aí uma aporia, dado que seria de difícil compreensão, à luz da teoria da relação jurídica (BETTI, 1969, p. 26), a existência de uma situação jurídica oponível sem a presença de um sujeito passivo determinado - como sói acontecer, por exemplo, numa relação proprietária. Nesta, há um vínculo jurídico que une a pessoa titular e o bem apropriado, sem que haja a necessidade de uma segunda pessoa para garantir o aproveitamento econômico do bem, como exposto no tópico anterior. Dessa forma, causa estranheza a defesa de existência de uma relação jurídica proprietária sem a necessária presença de um sujeito não proprietário, a quem é vetorizado o vínculo real (PERLINGIERI, 2008, p. 929).

O fundamento da crítica se calca no pressuposto teórico de que a presença de uma pessoa em um dos polos da relação jurídica é de sua essência, quer dizer, não haveria a possibilidade de existir, ou persistir existindo, uma relação jurídica em que a ela faltasse, de modo duradouro, uma pessoa a intitular uma de suas posições jurídicas, pois não haveria a possibilidade de existir um direito sem titular (PERLINGIERI, 2008, p. 732).$^{46} \mathrm{~A}$ Doutrina que se seguiu, entretanto, desenvolveu construção teórica que melhor enquadra as vicissitudes fáticas das várias modalidades de relações jurídicas. Fê-lo ao retirar o sujeito de direito do bojo intrínseco de uma relação, colocando-o como elemento externo que, ocasionalmente - mas não obrigatoriamente - pode ser titular de uma determinada situação jurídica. Nesse sentido, explica Pietro Perlingieri (2008, p. 743):

A ligação essencial do ponto de vista estrutural é aquela entre centros de interesses. O sujeito é somente um elemento externo à relação jurídica porque externo à situação: é somente o titular, às vezes ocasional, de uma ou de ambas as situações que compõem a relação jurídica; de maneira que não é indispensável referir-se à noção de sujeito para individuar o núcleo da relação jurídica.

\footnotetext{
A conclusão semelhante chega Pablo Renteria (2016, p. 29).

Cf. também Roberta Mauro Media Maia (2013, p. 159).

Transitoriamente, a doutrina há muito já admitia essa hipótese, como no caso da herança jacente, regulamentada atualmente pelos artigos 1.819 ao 1.823 do Código Civil (PEREIRA, 2011, p. 57). Para uma posição crítica à expressão "herança jacente", cf. Francisco Cavalcanti Ponte de Miranda (2012d, p. 155-157).
} 
O que é essencial é a ligação entre um interesse e um outro, entre uma situação, determinada ou determinável, e uma outra. É preferível, portanto, a doutrina que define a relação jurídica como ligação entre situações subjetivas.

Nesse modelo teórico, a propriedade do bem se enquadraria como relação jurídica. Isso ocorre porque, embora possa lhe faltar, em um sem número de vezes, um sujeito de direito a quem seja direcionado o dever jurídico de abstenção - o não agir contra o aproveitamento econômico do bem pelo proprietário, como antes reportado -, haveria, permanentemente, um centro de interesses a ser potencialmente titulado por toda a coletividade de não proprietários (PERLINGIERI, 2008, p. 929). Assim, seria possível a defesa da existência de uma relação jurídica substancializada por uma obrigação passiva universal - com eficácia erga omnes, pois. ${ }^{47}$ Tal configuração também não esteve isenta de críticas, tendo-se falado mesmo que representaria um absurdo linguístico e prático (ASCENSÃO, 1962, p. 27). O principal argumento é o de que seria uma construção estritamente fictícia, descompromissada com sua factibilidade (ASCENSÃO, 1962, p. 28-29).

A fim de tentar estabilizar a questão, a doutrina tem feito uma revisão cuidadosa e sofisticada dos pressupostos sobre os quais fora construído o entendimento de que às situações jurídicas reais seria garantida eficácia universal. Especialmente quanto à pretensa distinção estrutural em relação às situações jurídicas obrigacionais, que, de acordo com o discurso até então prevalecente, teriam eficácia relativa apenas às pessoas a elas vinculadas por convenção ou por força legal. Os obstáculos encontrados para a construção de uma estável teoria da relação jurídica, harmônica e congruente com as peculiaridades, tanto das situações reais quanto das obrigacionais, derivariam de uma confusão feita entre os conceitos de relatividade e oponibilidade (MAIA, 2013, p. 160-161).

Não seriam eles conceitos opostos alternativamente, mas complementares. Seriam dois aspectos, um interno e outro externo, de um mesmo fenômeno: a tutela das situações jurídicas. Ao primeiro, a relatividade, caberia a força interna de uma determinada situação, vinculando as partes a ela diretamente ligadas. Ao segundo, a oponibilidade, caberia a força externa dessa mesma situação, correspondente à existência de sua repercussão no meio social, cognoscível e, portanto, potencialmente oponível a toda a universalidade de pessoas não titulares (MAIA, 2013, p. 162).

As duas características são encontradas tanto nas situações jurídicas reais quanto nas obrigacionais, variando tão somente as suas intensidades. Embora não se negue que as situações jurídicas reais têm oponibilidade erga omnes, não Ihes falta também relatividade pela produção de efeitos internos de si diretamente decorrentes. É o caso ocorrente, por exemplo, na servidão em relação ao prédio dominado ou na superfície onerosa, em que se pode individuar com precisão quais seriam as pretensões jurídicas exigiveis por quem e a quem (MAIA, 2013, p. 162).

Ademais, não se nega às situações jurídicas obrigacionais a oponibilidade a quem quer que seja, ainda que não esteja relativamente obrigado ao adimplemento da sua específica prestação. Por se tratar de característica referente à tutela da situação contra externalidades, também a uma situação obrigacional se exige refreamento social, de modo a garantir que as suas existência e eficácia não sejam afetadas por atuações deliberadas de terceiros. Portanto, ainda que certa pessoa não esteja relativamente vinculada ao cumprimento de determinada obrigação, a ordem jurídica garante às partes que travam uma relação jurídica obrigacional a proteção contra ataques externos. Daí se verificar a existência de oponibilidade, também nas situações jurídicas obrigacionais, a poder gerar responsabilização civil de terceiros que embaracem o normal desenvolvimento de uma relação obrigacional do seu orgânico fim: o adimplemento da prestação. ${ }^{48}$

Há ainda as obrigações a que a lei civil brasileira expressamente dá eficácia universal, real ou erga omnes - como se preferir denominá-las. É o caso, especialmente, das cláusulas de vigência nos contratos de locação, que, devidamente averbadas nos registros cartorários competentes, garantem à parte locatária

\footnotetext{
47 Em um viés crítico, cf. José de Oliveira Ascensão (1962, p. 26-27).

48 Cf. Pietro Trimarchi (1983, p. 217-236); Mário Júlio de Almeida Costa (2009, p. 521-530); Paula Greco Bandeira (2007, p. 79-127). Sobre o adimplemento ser o fim da obrigação, cf. Clóvis do Couto e Silva (2006).
} 
o respeito às obrigações firmadas com a parte originariamente locadora, mesmo no caso de alienação do bem após a conclusão do contrato. ${ }^{49-50}$ Assim, conclui Roberta Mauro Medina Maia (2013, p. 185):

Desse modo, a oponibilidade erga omnes e a obrigação passiva universal, seu consectário lógico, não representam uma peculiaridade dos direitos reais, mas são conceitos inerentes àquele de direito subjetivo ou, se assim se preferir, constituem mecanismo indispensável de proteção, pelo ordenamento jurídico, dos bens ou faculdades que atribui aos indivíduos. Nesse sentido, é forçoso reconhecer que a oponibilidade erga omnes é indispensável à existência e à proteção dos direitos de um modo geral, pois, se não se impusesse a cada um o dever de respeitar as prerrogativas de seus semelhantes, tais direitos restariam sem qualquer valor.

Portanto, a oponibilidade erga omnes não é atributo exclusivo das situações jurídicas reais, uma vez que também é verificável nas obrigacionais. Não serve, pois, como traço distintivo à qualificação, real ou obrigacional, de uma situação jurídica eventualmente em análise.

\subsection{Registro e publicidade}

Estipula a lei civil brasileira que, em regra, "os direitos reais sobre coisas móveis, quando constituídos, ou transmitidos por atos entre vivos, só se adquirem com a tradição", ${ }^{51}$ e que os "direitos reais sobre imóveis constituídos, ou transmitidos por atos entre vivos, só se adquirem com o registro no Cartório de Registro de Imóveis dos referidos títulos". ${ }^{22} \mathrm{O}$ desiderato legal a exigir a tradição ou o registro para a aquisição de uma situação jurídica real é o tornar pública a sua titularidade e, assim, perfeitamente oponível a quem quer que seja. Ambos servem ao princípio da publicidade, condensador de quatro principais atributos: publicidade em sentido estrito, autenticidade, segurança e eficácia (RODRIGUES, 2016, p. 11).53-54

A função de tornar público um fato jurídico é torná-lo cognoscível a qualquer pessoa, de modo a otimizar a proteção ao titular de um direito contra invasões, em sentido lato, à sua esfera de interesses tutelados pelo ordenamento jurídico. No caso da tradição, dá-se uma publicidade de fato; no caso do registro, uma publicidade de direito. ${ }^{55} \mathrm{O}$ segundo tipo, registral, tem maior aptidão para garantir a almejada segurança jurídica, pois permite a reunião em um competente e referencial repositório público - a todos acessível, pois -, no qual constarão informações históricas presumivelmente verdadeiras sobre fatos e relações jurídicas em geral. É da mais ampla cognoscibilidade, mesmo por quem não tenha, por exemplo, testemunhado um determinado fato ou não tenha participado de uma determinada contratação. ${ }^{56}$

Antes do Código Civil de 1916, não se exigia o registro do título translativo para que houvesse a aquisição de propriedade imobiliária; "considerava-se, então, que a propriedade se transmitia exclusivamente pelo contrato, sem a necessidade de outra qualquer exigência" (PEREIRA, 2009, p. 100). ${ }^{57}$ Atualmente, no Brasil, desde a primeira codificação do século passado, passou-se a adotar o sistema registral de transcrição de títulos para os bens imóveis, inspirado no direito alemão, ${ }^{58}$ por trazer maior segurança jurídica ao tráfego

49 "Código Civil, art. 576. Se a coisa for alienada durante a locação, o adquirente não ficará obrigado a respeitar o contrato, se nele não for consignada a cláusula da sua vigência no caso de alienação, e não constar de registro. / $\S 1^{\circ} \mathrm{O}$ registro a que se refere este artigo será o de Títulos e Documentos do domicílio do locador, quando a coisa for móvel; e será o Registro de Imóveis da respectiva circunscrição, quando imóvel".

50 "Lei Federal n. ${ }^{\circ} 8.245 / 1991$, art. $8^{\circ}$. Se o imóvel for alienado durante a locação, o adquirente poderá denunciar o contrato, com o prazo de noventa dias para a desocupação, salvo se a locação for por tempo determinado e o contrato contiver cláusula de vigência em caso de alienação e estiver averbado junto à matrícula do imóvel".

51 "Código Civil, art. 1.226. Os direitos reais sobre coisas móveis, quando constituídos, ou transmitidos por atos entre vivos, só se adquirem com a tradição".

52 "Código Civil, art. 1.227. A aquisição da propriedade imóvel por usucapião ocorre pelo cumprimento no mundo dos fatos dos requisitos legais, sendo a sentença que a reconhece meramente declaratória, servindo de título para o posterior registro - Código Civil, arts. 1.238 ao 1.244 ”. Cf. Francisco Cavalcanti Ponte de Miranda (2016, p. 273-327).

53 "Lei Federal $n .^{\circ} 8.935 / 1994$, art. $1^{\circ}$. Serviços notariais e de registro são os de organização técnica e administrativa destinados a garantir a publicidade, autenticidade, segurança e eficácia dos atos jurídicos".

54 "Lei Federal n. ${ }^{\circ} 6.015 / 1973$, art. $1^{\circ}$. Os serviços concernentes aos Registros Públicos, estabelecidos pela legislação civil para autenticidade, segurança e eficácia dos atos jurídicos, ficam sujeitos ao regime estabelecido nesta Lei".

55 A classificação é de Salvatore Pugliatti (1989, passim).

56 "O que motiva a existência de registros públicos é a necessidade de conferir a terceiros segurança jurídica quanto às relações neles refletidas" (REsp 1124506/RJ, Rel. ministra Nancy Andrighi, Terceira Turma, julgado em 19/06/2012, DJe 14/11/2012).

57 Para uma apresentação dos sistemas de aquisição da propriedade imobiliária, cf. Clóvis Beviláqua (1946, p. 143-150); Augusto Teixeira de Freitas (2003, p. LIV-LXI); Lafayette Rodrigues Pereira (1956, p. 127-158); Caio Mário da Silva Pereira (2009, p. 100-107) e Orlando Gomes (2012, p. 151-152). Para uma revisão da história do direito registral imobiliário no Brasil, cf. Nicolau Balbino Filho (2012, p. 17-50).

58 Cf. Cláudia Lima Marques (1997, p. 11-37). 
negocial. ${ }^{59}$ Todavia um ponto diferencial do sistema do registro imobiliário brasileiro é a relatividade da presunção de veracidade do teor do registro, diferentemente do que ocorre no direito tedesco, em que a presunção é absoluta por conta do princípio da abstração lá vigente. ${ }^{60}$

Já quanto aos bens móveis, embora a aquisição da plena propriedade em regra prescinda de registro de título, não há vedação para que seja feito assentamento notarial, ${ }^{61}$ isto é, embora o registro seja imprescindível para a aquisição da propriedade imobiliária, a anotação cartorária não é exclusiva dessa espécie, podendo ocorrer também na propriedade mobiliária. Nesse caso, não terá, em regra, função constitutiva, mas declarativa. ${ }^{62}$ Servirá, preponderantemente, para dar mais ampla e fácil publicidade a uma titularidade e, assim, aumentar a segurança jurídica para o interessado contra atos de terceiros (MAIA, 2013, p. 235).

Todavia, em não sendo o registro um ato obrigatório por lei nesse caso, caberá ao interessado comprovar, na eventualidade de se sentir prejudicado, que o terceiro teria tido efetivamente conhecimento da situação jurídica tornada pública. Não se reputa presumível esse conhecimento, devendo ser demonstrado efetivamente, nas circunstâncias do caso concreto. Essa é uma diferença relevante quanto ao valor probatório dos documentos cujo registro público é obrigatório em relação àqueles em que não o é. No primeiro caso, é ônus de eventuais terceiros demonstrar que as informações relevantes ao caso concreto não constam nas serventias cartorárias ou que, constantes, não exprimem a verdade fática. No segundo, é dever do interessado comprovar tanto o registro do documento pertinente na serventia competente quanto a sua ciência pelo eventual terceiro (MAIA, 2013, p. 235).

Entretanto a exigência legal da prévia publicidade para a produção de efeitos perante terceiros - quanto aos interesses patrimoniais - não ocorre apenas em relação às situações jurídicas reais, como ilustrativamente apontado em relação à propriedade anteriormente..$^{63}$ Dá-se, também, em relação a situações jurídicas obrigacionais, como bem caracterizadamente ocorre com as cláusulas de vigência de contratos de locação. Além dessa hipótese, a Lei dos Registros Públicos prevê outras em que necessariamente deve haver o prévio registro de situações obrigacionais para que possam surtir efeitos em relação a terceiros, ${ }^{64}$ afora possibilitar, exemplificativamente, a transcrição no registro de títulos e documentos dos instrumentos particulares, para a prova das obrigações convencionais de qualquer valor, e, facultativamente, de quaisquer documentos, para sua conservação. ${ }^{65}$

Com a progressiva reorientação econômica, que tem modificado a produção de riquezas em todo o mundo, dando protagonismo às empresas que exploram serviços de interface entre os consumidores e os fornecedores, em detrimento ao modelo que concedia primazia à propriedade de bens, tem crescido a importância de se garantir segurança jurídica às relações contratuais ${ }^{66}$ pois os créditos têm assumido a posição de locomotiva nesse novo cenário, o que demanda ferramental eficiente para a estabilidade dos respectivos negócios jurídicos (RODRIGUES, 2016, p. 146):

Nas sociedades contemporâneas os direitos pessoais se destacam como fontes geradoras de riquezas, o que explica a preocupação dos diferentes sistemas jurídicos em formatar ferramentas legais que

59 Código Civil de 1916, art. 530, I. Código Civil de 2002, art. 1.227. A respeito do sistema registral alemão, cf. Mônica Jardim (2005, p. 213-238). Sobre a função socioeconômica da publicidade registral imobiliária, cf. Marcelo Salaroli de Oliveira (2010, p. 31-39).

60 Orientação doutrinária consolidada no Enunciado 503 da V Jornada de Direito Civil do Conselho da Justiça Federal: "É relativa a presunção de propriedade decorrente do registro imobiliário, ressalvado o sistema Torrens". Sobre o sistema Torrens, cf. Décio Antônio Erpen (2011, p. 305-322). Sobre o princípio da abstração no direito alemão e um comparativo com o direito registral brasileiro, cf. Erasmo Marcos Ramos (2003, p. 38-76) e Leonardo Brandelli (2016, p. 57-70).

61 Há bens móveis cujos direitos de propriedade devem ser registrados publicamente, como, e.g.: (i) os veículos de uso não bélico automotores,

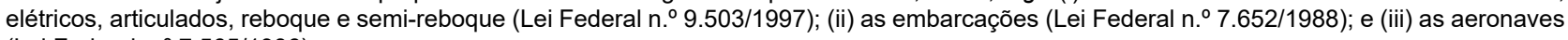
(Lei Federal n. $\left.{ }^{\circ} 7.565 / 1986\right)$.

62 Hipótese em que a lei exige o registro de alienação de bens móveis para o aperfeiçoamento aquisitivo se dá na transferência de ações nominativas, prevista no art. $31, \S 1^{\circ}$, da Lei Federal $n .^{\circ} 6.404 / 1976$, que dispõe sobre as sociedades por ações. Precedente do Superior Tribunal de Justiça confirmou essa interpretação em acórdão assim ementado: "Sociedade por ações - ações nominativas - transferência. A pretensão ao exercício de direito, relativamente a sociedade, por parte de acionista, vincula-se a averbação do titulo aquisitivo no livro de 'registro de ações nominativas'. Corretamente postulado o direito de recesso por quem figura naquele livro e não por terceiro que, mediante procuração em causa própria, teria adquirido as ações" (REsp 40.276/RJ, Rel. ministro Eduardo Ribeiro, Terceira Turma, julgado em 07/12/1993, DJ 07/03/1994, p. 3663).

63 A orientação dada à propriedade também vale para as outras espécies reais. É o caso, por exemplo, das garantias reais constantes em cédulas de crédito bancário emitidas por ocasião de financiamento de incorporações imobiliárias, como preceituado pela Lei Federal n. ${ }^{\circ} 10.931 / 2004$, art. 42. Em tópico a essa questão relacionada, cf. Milena Donato Oliva e Pablo Renteria (2015b, p. 103-136).

64 Lei Federal n. ${ }^{\circ} 6.015 / 1973$, art. 129.

65 Lei Federal n. ${ }^{\circ} 6.015 / 1973$, art. 127, I e VII.

66 Cf. Tom Goodwin (Disponível em: https://techcrunch.com/2015/03/03/in-the-age-of-disintermediation-the-battle-is-all-for-the-customer-interface/. Acesso em: 25 set. 2017). 
permitam a circulação dessa categoria de direitos de modo seguro, eficiente e constante, vale dizer, estabelecer um marco regulatório transparente e estável que possibilite a transferência dos direitos pessoais e irrigue a circulação das relações de créditos correspondentes.

Por isso, pode-se concluir que "não é a natureza de um direito que lhe tornará, por si só, oponível perante terceiros, mas a publicidade a ele eventualmente conferida" (MAIA, 2013, p. 193). Assim sendo, mais abrangente será a eficácia de uma determinada situação jurídica quanto mais publicidade a ela se der, especialmente por meio dos registros públicos. Portanto, a possibilidade de se dar publicidade por meio do registro também não é atributo exclusivo das situações jurídicas reais, uma vez que é possível, outrossim, nas obrigacionais. Não serve, pois, como traço distintivo à qualificação (real ou obrigacional) de uma situação jurídica eventualmente em análise.

\subsection{Preferência}

A preferência historicamente esteve ligada aos direitos reais de garantia. Classicamente, essa característica tem sido conceituada como sendo "um privilégio em benefício do credor garantido, no sentido de que the confere um direito de prelação ou preferência no recebimento" (PEREIRA, 2009, p. 279) de um determinado crédito. No caso de eventual inadimplemento por parte do devedor, seria possibilitado ao credor - na hipoteca e no penhor - excutir o bem dado em garantia por sua venda judicial forçosa, sendo o valor apurado destinado prioritariamente à satisfação do credor titular da referente situação real de garantia em relação a outros eventuais credores em comum (GOMES, 2012, p. 350).

Embora atualmente não se negue que tal característica continue a existir nas situações reais de garantia, o conceito de preferência não mais a ela se resume. Há um alargamento, que faz com que possa ser tal atributo também verificável em situações reais de fruição e, até mesmo, com algumas particularidades, em situações obrigacionais. Isso faz com que também essa definição limítrofe entre direitos reais e obrigações se torne mais flexível, e é motivo de intensa discussão teórica sobre qual seria a classe do direito de preferência: real ou pessoal. ${ }^{67}$ Talvez a própria busca por sua natureza jurídica seja descabida, tendo-se em conta que os limites conceituas dessa classificação têm sido fluidificados. Mais relevante que a feição estrutural de uma situação jurídica patrimonial é a sua função no caso concreto. ${ }^{68}$

De fato, é importante pontuar a releitura funcional que a doutrina tem feito a respeito do que seja e para que serve uma garantia nas relações civis. A crítica tem por núcleo essencial o entendimento de que ela, pessoal ou real, cumpre a sua função ainda que haja o estrito adimplemento da obrigação pelo devedor. Assim sendo, não teria função apenas remediadora em caso de inadimplemento, em uma perspectiva patológica. Teria também função preventiva, a fim de assegurar a estabilização da relação obrigacional, diluindo os riscos jurídico-econômicos e quiçá barateando o crédito. Há, desse modo, atuação também quando a relação obrigacional se desenvolve sem sobressaltos, alcançando o seu fim natural, que é o adimplemento (SILVA, 2006, p. 168). Nesse sentido, Pablo Renteria (2016, p. 148):

\footnotetext{
Sublinhe-se que a garantia cumpre sua função ainda que, em virtude do adimplemento da obrigação, não seja necessário acioná-la. Nesse tocante, há de se afastar da perspectiva repressiva que, sobrepondo, no exame da relação jurídica, o momento patológico ao fisiológico, considera que a garantia revela a sua utilidade apenas quando é empregada para remediar à violação do crédito.
}

Assim sendo, se às garantias não se deve atribuir às garantias um papel apenas em momentos patológicos das relações obrigacionais, semelhante atribuição deve ser feita ao direito de preferência. Explica-se: a função deste não se identifica com a excussão ou retenção do bem para percepção de frutos e rendimentos; revela-se, sim, na colocação da pessoa que a titulariza em uma posição privilegiada em relação a outros credores. Desse modo, precede ao próprio momento da realização do crédito, de maneira tal que ao direito de preferência devem ser reconhecidos contornos mais amplos. Pode-se, por isso, atribuir a ele uma prioridade que é dada ao seu titular para a assunção de determinada posição jurídica. 
Por sua vez, essa prioridade pode ser encontrada não apenas nos direitos reais de garantia, mas também nos de fruição, a conferir ao titular de uma situação jurídica real prioridade na aquisição de um determinado bem jurídico em eventual alienação. Há variadas hipóteses expressamente previstas na lei civil brasileira. É o caso, por exemplo, da preferência conferida (i) ao condômino de coisa indivisível para a aquisição de parte de outro condômino em caso de alienação a estranhos; ${ }^{69-70-71}$ (ii) mutuamente ao superficiário e ao proprietário do imóvel na aquisição, em igualdade de condições à da oferta, da propriedade ou do direito de superfície em caso de alienação; ${ }^{72}$ (iii) ao titular da construção-base e da laje, no caso de alienação de qualquer das unidades sobrepostas; ${ }^{73} \mathrm{e}$ (iv) aos proprietários de imóveis atravessados por aquedutos para a canalização de águas supérfluas. ${ }^{74}$

Além disso, há previsão legal de preferência também nas relações obrigacionais. ${ }^{75}$ É o caso, exemplificativamente, do direito de prelação dado (i) ao credor originário só em parte reembolsado, no caso de sub-rogação, para cobrança da dívida restante; ${ }^{76}$ (ii) ao locatário quando da alienação do bem imóvel urbano pelo locador; ${ }^{77}$ (iii) ao arrendatário quanto à renovação do contrato de arrendamento rural; ${ }^{78}$ (iv) ao parceiro, na hipótese de renovação de contrato de parceria agrícola, pecuária, agroindustrial e extrativa. ${ }^{79}$ Ocorre também na insolvência civil ${ }^{80}$, no aumento de capital de sociedade limitada, ${ }^{81}$ na sucessão ${ }^{82}$ e na falência. ${ }^{83}$

A lei civil brasileira ainda permite que, além dos casos expressamente legislados, os particulares possam convencionalmente estipular direitos de preferência. É a circunstância, e.g., do pacto adjeto à compra e venda que estipula a preempção, que "impõe ao comprador a obrigação de oferecer ao vendedor a coisa que aquele vai vender, ou dar em pagamento, para que este use de seu direito de prelação na compra, tanto por tanto". ${ }^{84}$ Podem estes, inclusive, ser opostos a terceiros se lhes for dada a devida publicidade, como sói ocorrer no direito de preferência à aquisição de ações de companhias. ${ }^{85}$

69 "Código Civil, art. 504. Não pode um condômino em coisa indivisível vender a sua parte a estranhos, se outro consorte a quiser, tanto por tanto. O condômino, a quem não se der conhecimento da venda, poderá, depositando o preço, haver para si a parte vendida a estranhos, se o requerer no prazo de cento e oitenta dias, sob pena de decadência". Há precedente do Superior Tribunal de Justiça que estipulou não haver ordem de preferência internamente entre condôminos, mas tão somente em relação a estranhos: REsp 1137176/PR, Rel. ministro Marco Buzzi, Quarta Turma, julgado em 16/02/2016, DJe 24/02/2016. Há também, do mesmo tribunal, orientação jurisprudencial no sentido de igual inteligência jurídica ser aplicável a bens que estejam em estado de indivisão, mas sejam divisíveis: REsp 1207129/MG, Rel. ministro Luis Felipe Salomão, Quarta Turma, julgado em 16/06/2015, DJe 26/06/2015. "Uma vez ultimado o negócio sem observância da notificação prévia do condômino, a solução da questão somente pode se dar na via judicial, pela ação de preferência c.c. adjudicação compulsória" (REsp 1324482/SP, Rel. ministro Moura Ribeiro, Terceira Turma, Julgado Em 05/04/2016, Dje 08/04/2016)

70 "Código Civil, art. 1.322. Quando a coisa for indivisível, e os consortes não quiserem adjudicá-la a um só, indenizando os outros, será vendida e repartido o apurado, preferindo-se, na venda, em condições iguais de oferta, o condômino ao estranho, e entre os condôminos aquele que tiver na coisa benfeitorias mais valiosas, e, não as havendo, o de quinhão maior".

71 "Lei Federal n. ${ }^{\circ} 4.591 / 1964$, art. $63, \S 3^{\circ}$. No prazo de 24 horas após a realização do leilão final, o condomínio, por decisão unânime de AssembléiaGeral em condições de igualdade com terceiros, terá preferência na aquisição dos bens, caso em que serão adjudicados ao condomínio".

72 "Código Civil, art. 1.373. Em caso de alienação do imóvel ou do direito de superfície, o superficiário ou o proprietário tem direito de preferência, em igualdade de condições".

73 "Código Civil, art. 1.510-D. Em caso de alienação de qualquer das unidades sobrepostas, terão direito de preferência, em igualdade de condições com terceiros, os titulares da construção-base e da laje, nessa ordem, que serão cientificados por escrito para que se manifestem no prazo de trinta dias, salvo se o contrato dispuser de modo diverso".

74 "Código Civil, art. 1.296. Havendo no aqueduto águas supérfluas, outros poderão canalizá-las, para os fins previstos no art. 1.293, mediante pagamento de indenização aos proprietários prejudicados e ao dono do aqueduto, de importância equivalente às despesas que então seriam necessárias para a condução das águas até o ponto de derivação. / Parágrafo único. Têm preferência os proprietários dos imóveis atravessados pelo aqueduto".

75 Reportando-se ao direito português, em viés crítico a essa leitura, cf. João de Matos Antunes Varela (2000, pp. 175-182)

76 "Código Civil, art. 351. O credor originário, só em parte reembolsado, terá preferência ao sub-rogado, na cobrança da dívida restante, se os bens do devedor não chegarem para saldar inteiramente o que a um e outro dever".

77 "Lei Federal n. ${ }^{\circ} 8.245 / 1991$, art. 27. No caso de venda, promessa de venda, cessão ou promessa de cessão de direitos ou dação em pagamento, o locatário tem preferência para adquirir o imóvel locado, em igualdade de condições com terceiros, devendo o locador dar-Ihe conhecimento do negócio mediante notificação judicial, extrajudicial ou outro meio de ciência inequívoca".

78 "Lei Federal n. ${ }^{\circ} 4.504 / 1964$, art. 95. Quanto ao arrendamento rural, observar-se-ão os seguintes princípios: IV - em igualdade de condições com estranhos, o arrendatário terá preferência à renovação do arrendamento, devendo o proprietário, até 6 (seis) meses antes do vencimento do contrato, fazer-lhe a competente notificação extrajudicial das propostas existentes".

79 "Lei Federal n. ${ }^{\circ} 4.504 / 1964$, art. 96. Na parceria agrícola, pecuária, agro-industrial e extrativa, observar-se-ão os seguintes princípios: II - expirado o prazo, se o proprietário não quiser explorar diretamente a terra por conta própria, o parceiro em igualdade de condições com estranhos, terá preferência para firmar novo contrato de parceria".

80 Código Civil, arts. 955 ao 965.

81 "Código Civil, art. 1.081, $\S 1^{\circ}$. Até trinta dias após a deliberação, terão os sócios preferência para participar do aumento, na proporção das quotas de que sejam titulares".

82 "Código Civil, art. 1.795. O co-herdeiro, a quem não se der conhecimento da cessão, poderá, depositado o preço, haver para si a quota cedida a estranho, se o requerer até cento e oitenta dias após a transmissão".

83 Lei Federal n. ${ }^{0} 11.101 / 2005$, art. 83

84 Código Civil, art. 513. Cf. Carla Wainer Chalréo Lgow (2013, p. 12-14).

85 "Lei Federal n. ${ }^{\circ} 6.404 / 1976$, art. 40, parágrafo único. Mediante averbação nos termos deste artigo, a promessa de venda da ação e o direito de 
Enfim, o direito de preferência é um instituto polivalente (LGOW, 2013, p. 23), não sendo atributo exclusivo das situações jurídicas reais, uma vez que também é verificável nas obrigacionais. Não serve, pois, como traço distintivo à qualificação, real ou obrigacional, de uma situação jurídica eventualmente em análise.

\subsection{Direito de sequela}

Outra característica também costumeiramente relacionada como peculiaridade das situações jurídicas reais é o direito de sequela (COSTA, 1999, p. 72). Pode ele ser conceituado como o direito "que tem o titular de direito real de seguir a coisa em poder de todo e qualquer detentor ou possuidor" (GOMES, 2012, p. 20). ${ }^{86}$ Trata-se, pois, de uma faculdade de agir conferida ao seu titular a lhe permitir buscar e haver para si coisa a que tenha direito, onde quer que esteja, com quem quer que esteja (RENTERIA, 2016, p. 50).

Por outorgar ao seu titular esse largo direito de perseguir a coisa, tendo eficácia erga omnes, é associado aos direitos reais. Não o é em relação às obrigações, pois ordinariamente o inadimplemento por parte do devedor acarreta a conversão da obrigação específica em perdas e danos. ${ }^{87}$ Portanto, em regra, não caberia ao credor direcionar, por exemplo, uma pretensão aquisitiva em relação a terceiro que tivesse adquirido de boa-fé junto ao devedor coisa àquele reservada. Nessa hipótese, restaria ao credor apenas direcionar ao devedor uma pretensão de reparação por perdas e danos - ainda que o terceiro venha a se tornar solidário caso tenha procedido de má-fé..$^{88}$

Ocorre que nem sempre será impossibilitado ao credor perseguir a coisa mesmo que já esteja com terceiro, originariamente não obrigado consigo. É o caso, marcadamente, do direito de preferência nos contratos de locação de imóveis urbanos a que se tenha dado eficácia real mediante o registro público. Em tendo sido dada a correta publicidade ao contrato de locação, por sua tempestiva averbação no competente cartório de registro de imóveis, no caso de o locatário ser preterido no seu direito de preferência, "poderá reclamar do alienante as perdas e danos ou, depositando o preço e demais despesas do ato de transferência, haver para si o imóvel locado". ${ }^{89}$ É interessante observar que a averbação não é exigida nos contratos de arrendamento rural para que similares efeitos sejam gerados, muito por conta de serem possíveis contratações mais rudimentares. ${ }^{90} \mathrm{~A}$ esse respeito, esclarece Carla Wainer Chalréo Lgow (2013, p. 46-47):

Para além do sistema do numerus clausus, que não parece ter incluído a preferência no rol dos direitos reais, a relação prelatícia, ao estabelecer para o sujeito passivo um dever de contratar com o preferente, desde que preenchidos certos pressupostos e manifestada a intenção deste último em exercer o seu direito, contém as características típicas de um direito obrigacional: o sujeito ativo dispõe de uma prestação exigível perante o sujeito passivo. Tais características permanecem mesmo diante da alienação do bem objeto do contrato preferível a terceiro, desde que o direito do preferente seja dotado de eficácia real. É razoável interpretar, então, que a intenção do legislador, ao prever que o preferente poderá, diante da violação de seu direito mediante alienação a terceiro, 'haver para si' o bem, tinha sido justamente atribuir eficácia real à obrigação prelatícia, de modo que a execução específica do direito do preferente possa alcançar não só o sujeito passivo, como também o terceiro com quem ele tenha contratado, perante quem o direito de preferência será também oponível.

preferência à sua aquisição são oponíveis a terceiros".

86 Em sentido semelhante, Edmundo Gatti (1976, p. 70).

87 "Código Civil, art. 389. Não cumprida a obrigação, responde o devedor por perdas e danos, mais juros e atualização monetária segundo índices oficiais regularmente estabelecidos, e honorários de advogado".

88 "Código Civil, art. 518. Responderá por perdas e danos o comprador, se alienar a coisa sem ter dado ao vendedor ciência do preço e das vantagens que por ela lhe oferecem. Responderá solidariamente o adquirente, se tiver procedido de má-fé”. Sílvio de Salvo Venosa (2004a, p. 178) faz relevante destaque: "É importante notar que na compra e venda, desde a origem, o direito de preempção não confere um direito real sobre a coisa alienada".

89 Lei Federal n. ${ }^{\circ}$ 8.245/1991, art. 33. Há julgado do Tribunal de Justiça de São Paulo nesse exato sentido: "LOCAÇÃO DE IMÓVEIS. Ação de adjudicação compulsória Direito de preferência Ação que busca viabilizar o exercício do direito de preferência pela locatária, preterida na venda do imóvel locado - Necessidade de prévia averbação do contrato de locação (pelo menos 30 dias antes da alienação) no registro de imóveis Exegese do art. 33 da Lei n. ${ }^{\circ} 8.245 / 91$ Registro simultâneo que afasta o direito de preferência Sentença mantida Recurso desprovido. (TJSP; Apelação 0028047-73.2010.8.26.0344; Relator (a): Carlos Nunes; Órgão Julgador: 33ª Câmara de Direito Privado; Foro de Marília - $3^{a}$. Vara Cível; Data do Julgamento: 22/09/2014; Data de Registro: 25/09/2014)".

90 "Lei Federal n. ${ }^{\circ} 4.504 / 1964$, art. 92. $§ 3^{\circ}$ No caso de alienação do imóvel arrendado, o arrendatário terá preferência para adquiri-lo em igualdade de condições, devendo o proprietário dar-Ihe conhecimento da venda, a fim de que possa exercitar o direito de perempção dentro de trinta dias, a contar da notificação judicial ou comprovadamente efetuada, mediante recibo. / $\S 4^{\circ} \mathrm{O}$ arrendatário a quem não se notificar a venda poderá, depositando o preço, haver para si o imóvel arrendado, se o requerer no prazo de seis meses, a contar da transcrição do ato de alienação no Registro de Imóveis. / $\S 8^{\circ}$ Para prova dos contratos previstos neste artigo, será permitida a produção de testemunhas. A ausência de contrato não poderá elidir a aplicação dos princípios estabelecidos neste Capítulo e nas normas regulamentares". 
Embora haja controvérsias na doutrina ${ }^{91}$ e na jurisprudência ${ }^{92}$ a respeito de dever ser o direito de preferência classificado como direito real ou pessoal - e sem prejuízo da construção de um direito patrimonial comum -, entende-se que há uma maior aproximação com as ditas situações jurídicas obrigacionais, tanto por não haver um regramento jurídico planificado às mais diversas previsões legais de direitos prelatícios quanto (e principalmente) por haver hipóteses legais em que expressamente não se dá eficácia real a uma preferência. ${ }^{93}$

Classificar o direito de preferência como situação real é inadequado, pois representaria transformar o efeito - o direito de sequela - em causa, ou seja, estar-se-ia fazendo essa classificação no sentido inverso: porque há sequela, é situação real, fechando-se já de saída, por completo, a possibilidade de também se verificar o ius persequendi em situações eminentemente obrigacionais. Como percebível pela leitura da legislação civil brasileira, essa última hipótese é, aqui, plenamente válida.

Dessa forma, vê-se que o direito de sequela não é atributo exclusivo das situações jurídicas reais, visto que também é efeito possível das obrigacionais. ${ }^{94}$ Portanto, igualmente não serve como traço distintivo por si só à qualificação, real ou obrigacional, de uma situação jurídica eventualmente em análise.

\section{Conclusão}

Pela discussão até aqui apresentada, é possível se chegar à conclusão de que - à luz do direito civil brasileiro vigente -, não há barreiras absolutas a justificar uma cisão dos interesses patrimoniais em categorias estanques, de situações reais ou pessoais. Por vezes, a propósito, a diferenciação entre direitos reais e direitos de crédito se baseia em uma petição de princípios: uns e outros seriam absolutos e relativos por alegadamente terem eficácia erga omnes ou restrita a algumas pessoas, e teriam eficácia erga omnes ou restrita a algumas pessoas por supostamente serem absolutos e relativos. Ao contrário do que defende essa artificiosa divisão (GOMES, 2012, p. 10), percebe-se que há, sim, notória permeabilidade nos regimes jurídicos, das variadas espécies de umas e outras, a demonstrar que existe maior proximidade entre ambas do que se supunha (PERLINGIERI, 2008, p. 896). ${ }^{95}$

Em outras palavras, conforme são flexibilizadas suas principais características distintivas (antes consideradas verdadeiro dogma do direito civil), passou-se a sustentar que, entre obrigações e direitos reais, não haveria uma diferença ontológica de base, mas sim particularizações de uma mesma raiz, cada qual com uma sistemática jurídica peculiar não suficiente para desnaturar a origem comum (MAIA, 2013, p. 276-277). Nesse sentido, há muito já se afirma que obrigações propter rem e obrigações com eficácia real, ${ }^{96}$ por exemplo, constituiriam evidentes flexibilizações, seja do caráter típico dos direitos reais, seja do caráter relativo dos direitos de crédito, a diminuir a distância entre as duas categorias. ${ }^{97}$

Tal processo, se não autoriza concluir como superada a dicotomia entre essas categorias, ao menos permite antever a proximidade de um direito comum, ou de um regime geral, das relações patrimoniais. Isso ocorreu, sobretudo, após a consagração da dignidade humana como o valor fundamental da ordem constitucional brasileira (MONTEIRO FILHO, 2008, p. 263), o que deslocou a summa divisio fundamental do direito civil para a dicotomia relações patrimoniais/relações existenciais (TEPEDINO, 2009, p. 13).

Cf. Silvia C. B. Opitz e Oswaldo Opitz (2013, p. 309-310).

2 Veja-se, ilustrativamente, julgados do Supremo Tribunal Federal (RE 58954, Relator(a): Min. Luiz Gallotti, Terceira Turma, julgado em 09/06/1967, DJ 30-08-1967 PP-02625 EMENT VOL-00700-01 PP-00266) e do Superior Tribunal de Justiça (REsp 164.442/MG, Rel. ministro Luis Felipe Salomão, Quarta Turma, julgado em 21/08/2008, DJe 01/09/2008).

93 "Código Civil, art. 518. Responderá por perdas e danos o comprador, se alienar a coisa sem ter dado ao vendedor ciência do preço e das vantagens que por ela lhe oferecem. Responderá solidariamente o adquirente, se tiver procedido de má-fé".

94 A sequela também nem sempre se fará possível nos direitos reais, como na hipótese da Súmula n 308 do Superior Tribunal de Justiça: "A hipoteca firmada entre a construtora e o agente financeiro, anterior ou posterior à celebração da promessa de compra e venda, não tem eficácia perante os adquirentes do imóvel" (Súmula 308, Segunda Seção, julgado em 30/03/2005, DJ 25/04/2005, p. 384). Sobre isso, cf. Milena Donato Oliva e Pablo Renteria (2015a, p. 218-236).

95 Em complemento, cf. Gustavo Tepedino, Heloisa Helena Barboza e Maria Celina Bodin de Moraes (2011, p. 486).

96 Cf. Miguel Maria de Serpa Lopes (1995, p. 46) e San Tiago Dantas (1939, p. 244).

97 Paralelamente a esse processo (e em grande parte por influência dele), os doutrinadores nacionais e estrangeiros também têm discorrido quanto às coligações entre situações obrigacionais - especialmente as de origem contratual -, no que toca às suas mútuas implicações com efeitos na qualificação contratual, na validade e na eficácia dos contratos. Cf. Carlos Nelson Konder (2009, p. 79-80) e Francisco Paulo de Crescenzo Marino (2009, p. 189) 
A funcionalização dos interesses patrimoniais aos existenciais tem provocado uma homogeneização no tratamento jurídico daqueles, em especial quanto aos critérios de aferição do merecimento de tutela. De fato, a análise funcional dos institutos jurídicos no caso concreto permite a reflexão crítica da dogmática das situações jurídicas reais e obrigacionais, a partir da qual é possível o estudo da viabilidade de construção e pertinência de uma disciplina "una" das situações jurídicas patrimoniais em geral. A respeito da releitura da cisão das situações subjetivas patrimoniais entre creditícias e reais, afirma Rafael Domingos Faiardo Vanzella (2012, p. 56):

[...] à dicotomia entre créditos - ou direitos subjetivos creditícios, direitos subjetivos obrigacionais ou, ainda, direitos subjetivos pessoais - e direitos subjetivos reais subjazem modelos sociais de assenhoramento dos bens econômicos. A contingência ressalta, na exata medida em que, pelas novas necessidades econômico-sociais, tanto o emprego desses modelos obsolesce-se quanto a apreciação dos bens econômicos transfigura-se. Assim, depara-se a experiência jurídica, a cada dia, com novos problemas práticos a partir dos quais aquela dicotomia - que, inversamente, é de certa forma estável - tem de ser analisada e, fatalmente, reconsiderada.

Dessa forma, torna-se pertinente - quiçá necessária - a construção de um regime jurídico comum aos interesses patrimoniais, isto é, que permita a aplicação de normativa extraída à luz da interpretação do caso concreto, sem definições apriorísticas de pretensas naturezas jurídicas, de modo a permitir que a função concretamente perseguida se torne o cerne em torno do qual deve ser feito a qualificação e o tratamento jurídico da relação. Isso equivale a dizer que a função concreta deve determinar a estrutura jurídica da situação, e não o inverso. Conforme a lição de Pietro Perlingieri (2008, p. 642):

$\mathrm{Na}$ identificação da função dever-se-á considerar os princípios e valores do ordenamento que a cada vez permitem proceder à valoração do fato. Ao valorar o fato, o jurista identifica a função, isto é, constrói a síntese global dos interesses sobre os quais o fato incide. A função do fato determina a estrutura, a qual segue - não precede - a função.

Com isso se quer dizer que é inadequado se definir abstratamente uma situação como real ou obrigacional, fechando-a em um regime jurídico parcelar previamente estabelecido em lei. O que se quer é dar flexibilidade a esse tratamento jurídico, não impossibilitando que a uma situação ordinariamente classificada como real sejam aplicadas normativas costumeiramente destinadas a uma obrigacional, ou o inverso. Uma vez que há uma matriz comum, igualmente há de existir um caminho interpretativo que possa ser aplicável para a qualificação jurídica de todas as situações subjetivas patrimoniais. Mais uma vez, Pietro Perlingieri (2008, p. 892):

As situações subjetivas patrimoniais podem ser objeto de uma abordagem unitária, embora ainda não tenha sido elaborada, interpretativamente, uma normativa comum que lhe sirva de referência. Esta normativa comum não se pode identificar exclusivamente com o direito das obrigações ou com aquele das relações reais, mas deve ser concebida como a síntese das disciplinas de todas as relações patrimoniais.

Esse viés abre muitas possibilidades para a construção de negócios jurídicos sofisticados, aos quais sejam possibilitados amplos ferramentais de modulação dos interesses patrimoniais envolvidos, a fim de que o fim econômico-individual concretamente perseguido seja mais perfeitamente atingido. Ainda que, para isso, o caso concreto precise revelar que, por vezes, uma típica situação jurídica real se comportaria como se obrigacional fosse, ou que a uma caracterizada situação jurídica obrigacional se dessem matizes de uma real (TEPEDINO, 2001). A respeito disso, faz a defesa Michele Giorgianni (1940, p. 171):

La tradizionale ripartizione dei diritti patrimoniali in reali e obbligatori merita invero di essere riveduta nel senso che, non solo [...] un rapporto obbligatorio può per avventura appartenere alla categoria dei diritti reali, ma altresi in quello che, in contrapposto alla categoria dei diritti reali, non esiste solo quella dei diritti obbligatori ma ne esistono altresi altre.

As características vistas anteriormente não são exclusivas nem uniformes para os direitos reais ou obrigações. Entre eles há diferenciações de intensidade, e não propriamente de essência. Destarte, o foco da qualificação jurídica deve estar na dimensão da eficácia de cada situação jurídica - na largueza de sua esfera de coexistência com outras situações, em uma perspectiva relacional. Por isso, enseja-se uma 
comum categorização dos interesses economicamente quantificáveis, que não seja estritamente nem real, nem obrigacional. Por fim, que seja, sim, simples e genericamente patrimonial.

\section{Referências}

ANDRADE, Darcy Bessone de Oliveira. Direitos reais. São Paulo: Saraiva, 1988.

ARONNE, Ricardo. Propriedade e domínio: reexame sistemático das noções nucleares de direitos reais. Rio de Janeiro: Renovar, 1999.

ASCENSÃO, José de Oliveira. As relações jurídicas reais. Lisboa: Livraria Morais, 1962.

ASCENSÃO, José de Oliveira. Direito civil: teoria geral: relações e situações jurídicas. 2. ed. São Paulo: Saraiva, 2010. v. 3.

ASCENSÃO, José de Oliveira. Introdução à ciência do direito. 3. ed. Rio de Janeiro: Renovar, 2005.

BALBINO FILHO, Nicolau. Direito imobiliário registral. 2. ed. São Paulo: Saraiva, 2012.

BANDEIRA, Paula Greco. Fundamentos da responsabilidade civil do terceiro cúmplice. Revista Trimestral de Direito Civil, Rio de Janeiro, ano 8, v. 30, p. 79-127, abr./jun. 2007.

BARBOSA, Pedro Marcos Nunes. Direito civil da propriedade intelectual: o caso da usucapião de patentes. 3. ed. Rio de Janeiro: Lumen Juris, 2016.

BARCELLONA, Pietro. L'individualismo proprietario. Torino: Ristampa, 1988.

BETTI, Emilio. Teoria geral do negócio jurídico. Coimbra: Coimbra Editora, 1969. t. 1.

BEVILÁQUA, Clóvis. Direito das coisas. 2. ed. Rio de Janeiro: Freitas Bastos, 1946. v. 1.

BOBBIO, Norberto. Da estrutura à função: novos estudos de teoria do direito. Barueri: Manole, 2007.

BOVE, Roberto. O direito real de servidão. In: DIP, Ricardo; JACOMINO, Sérgio (org.). Direito registral: propriedade e direitos reais limitados. São Paulo: Revista dos Tribunais, 2011. (Coleção doutrinas essenciais, v. V). p. 1327-1362.

BRANDELLI, Leonardo. Registro de imóveis: eficácia material. Rio de Janeiro: Forense, 2016.

CARVALHO, Orlando de. Direito das coisas: do direito das coisas em geral. Coimbra: Coimbra Editora, 2012.

COMPORTI, Marco. Contributo allo studio del diritto reale. Milano: Giuffrè, 1977.

COSTA, Dilvanir José da. O conceito de direito real. Revista de Informação Legislativa, Brasília, v. 36, n. 144, p. 71-79, out./dez. 1999.

COSTA, Mário Júlio de Almeida. A eficácia externa das obrigações: entendimento da doutrina clássica.

In: CAMPOS, Diogo Leite de (org.). Estudos em homenagem ao Prof. Doutor Manuel Henrique

Mesquita. Coimbra: Coimbra Editora, 2009. v. 1. p. 521-530.

DANTAS, Francisco Clementino San Tiago. O conflito de vizinhança e sua composição. Rio de Janeiro: Borsoi, 1939.

DANTAS, Francisco Clementino San Tiago. Programa de direito civil. 2. ed. Rio de Janeiro: Editora Rio, 1979. v. 1.

DANTAS, Francisco Clementino San Tiago. Programa de direito civil. 2. ed. Rio de Janeiro: Editora Rio, 1981. v. 3.

DÍEZ-PICAZO, Luis. Fundamentos del derecho civil patrimonial: las relaciones jurídico-reales, el registro de la propiedad, la posesión. 5. ed. Madrid: Thomson Civitas, 2008.

ERPEN, Décio Antônio. O registro Torrens e o sistema imobiliário atual. In: DIP, Ricardo; JACOMINO, Sérgio (org.). Direito registral: Registro imobiliário: dinâmica registral. São Paulo: Revista dos Tribunais, 2011. (Coleção doutrinas essenciais, v. VI). p. 305-322. 
FACHIN, Luiz Edson. Estatuto jurídico do patrimônio mínimo. 2. ed. Rio de Janeiro: Renovar, 2006. FREITAS, Augusto Teixeira de. Código civil: esboço. Rio de Janeiro: Departamento de Imprensa Nacional, 1952.

FREITAS, Augusto Teixeira de. Consolidação das leis civis. Prefácio de Ruy Rosado de Aguiar. [Ed. fac-sim]. Brasília: Senado Federal, Conselho Editorial, 2003.

GABBA, Carlo Francesco. Della proprietà usque ad sidera et ínferos: considerazioni intorno all'articolo 440 del Codice civile italiano. In: GABBA, Carlo Francesco. Questioni di diritto civile: diritto personale e diritto reale. 2. ed. Torino: Fratelli Bocca Editori, 1909. v. 1. p. 112.

GATTI, Edmundo. Teoría general de los derechos reales. Buenos Aires: Abeledo-Perrot, 1976.

GIORGIANNI, Michele. Contributo alla teoria dei diritti di godimento su cosa altrui. Milano: Giuffrè, 1940.

GOMES, Orlando. Direitos reais. 21. ed. Rio de Janeiro: Forense, 2012.

GONDINHO, André Osório. Direitos reais e autonomia da vontade: o princípio da tipicidade dos direitos reais. Rio de Janeiro: Renovar, 2001.

GOODWIN, Tom. The battle is for the customer interface. Tech Crunch, San Francisco, 3 mar. 2015.

Disponível em: https://techcrunch.com/2015/03/03/in-the-age-of-disintermediation-the-battle-is-all-for-thecustomer-interface/. Acesso em: 25 set. 2017.

HESSEN, Johannes. Teoria do conhecimento. São Paulo: Martins Fontes, 1999.

JARDIM, Mônica. O sistema registral germânico. Revista de Direito Imobiliário, São Paulo, ano 28, n. 59, p. 213-238, jul./dez. 2005.

KONDER, Carlos Nelson. Qualificação e coligação contratual. Revista Forense, Rio de Janeiro, ano 105, v. 406, p. 55-86, nov./dez. 2009.

LGOW, Carla Wainer Chalréo. Direito de preferência. São Paulo: Atlas, 2013.

MAIA, Roberta Mauro Medina. Teoria geral dos direitos reais. São Paulo: Revista dos Tribunais, 2013.

MARINO, Francisco Paulo de Crescenzo. Contratos coligados no direito brasileiro. São Paulo:

Saraiva, 2009.

MARQUES, Cláudia Lima. Cem anos de código civil alemão: o BGB de 1896 e o código civil brasileiro de 1916. Revista dos Tribunais, São Paulo, ano 86, n. 741, p. 11-37, jul. 1997.

MARTINS-COSTA, Judith. Usucapião de coisa incorpórea: breves notas sobre um velho tema sempre novo. In: TEPEDINO, Gustavo; FACHIN, Luiz Edson (org.). O direito e o tempo: embates jurídicos e utopias contemporâneas. Estudos em homenagem ao Professor Ricardo Pereira Lira. Rio de Janeiro: Renovar, 2008, p. 631-653.

MESQUITA, Manuel Henrique. Obrigações reais e ónus reais. Coimbra: Almedina, 1990.

MIRANDA, Francisco Cavalcanti Ponte de. Tratado das ações: ações declarativas. São Paulo: Revista dos Tribunais, 2016. t. 2.

MIRANDA, Francisco Cavalcanti Ponte de. Tratado de direito privado: parte geral. São Paulo: Revista dos Tribunais, 2012. t. 3.

MIRANDA, Francisco Cavalcanti Ponte de. Tratado de direito privado: parte especial. São Paulo: Revista dos Tribunais, 2012. t. 11.

MIRANDA, Francisco Cavalcanti Ponte de. Tratado de direito privado: parte especial. São Paulo: Revista dos Tribunais, 2012. t. 18.

MIRANDA, Francisco Cavalcanti Ponte de. Tratado de direito privado: parte especial. São Paulo: Revista dos Tribunais, 2012. t. 55. 
MONTEIRO, Washington de Barros. Curso de direito civil: direito das coisas. 29. ed. São Paulo: Saraiva, 1991. v. 3.

MONTEIRO FILHO, Carlo Edison do Rêgo. Pacto comissório e pacto marciano no sistema brasileiro de garantias. Rio de Janeiro: Processo, 2017.

MONTEIRO FILHO, Carlo Edison do Rêgo. Rumos cruzados do direito civil pós-1988 e do constitucionalismo de hoje. In: TEPEDINO, Gustavo (coord.). Direito civil contemporâneo: novos problemas à luz da legalidade constitucional. São Paulo: Atlas, 2008. p. 262-281.

NADER, Paulo. Curso de direito civil: obrigações. Rio de Janeiro: Forense, 2005. v. 2.

OLIVA, Milena Donato; RENTERÍA, Pablo. Incorporação imobiliária e direito do consumidor: notas sobre o Enunciado $n^{\circ} .308$ da Súmula da Jurisprudência do Superior Tribunal de Justiça. In: COSTA, Ilton Garcia da; DIAS, Clara Angélica Gonçalves; FIUZA, César Augusto de Castro (coord.). Direito civil constitucional. Florianópolis: CONPEDI, 2015. v. 1, p. 218-236. Disponível em: http://conpedi.danilolr. info/publicacoes/c178h0tg/84k8hu2h/8ZxrfFk78pa1oTNb.pdf. Acesso em: 02 ago. 2020.

OLIVA, Milena Donato; RENTERÍA, Pablo. Tutela do consumidor na perspectiva civil-constitucional: a cláusula geral de boa-fé objetiva nas situações jurídicas obrigacionais e reais e os Enunciados 302 e 308 da Súmula da Jurisprudência Predominante do Superior Tribunal de Justiça. Revista de Direito do Consumidor, São Paulo, ano 25, n. 101, p. 101-136, set./out. 2015.

OLIVEIRA, Marcelo Salaroli de. Publicidade registral imobiliária. São Paulo: Saraiva, 2010.

OPITZ, Silvia C. B.; OPITZ, Oswaldo. Curso completo de direito agrário. 7. ed. São Paulo: Saraiva, 2013.

PENTEADO, Luciano de Camargo. Direito das coisas. 3. ed. São Paulo: Revista dos Tribunais, 2014.

PENTEADO, Luciano de Camargo. Que coisa é a coisa? Reflexões em torno a um pequeno ensaio de Carnelutti. Revista de Direito Privado, São Paulo, ano 11, n. 39, p. 249-258, jul./set. 2009.

PEREIRA, Caio Mário da Silva. Instituições de direito civil: introdução ao direito civil; teoria geral de direito civil. 24. ed. Rio de Janeiro: Forense, 2011. v. 1.

PEREIRA, Caio Mário da Silva. Instituições de direito civil: direito reais. 20. ed. Rio de Janeiro: Forense, 2009. v. 4.

PEREIRA, Caio Mário da Silva. Instituições de direito civil: direito das sucessões. 18. ed. Rio de Janeiro: Forense, 2011. v. 6.

PEREIRA, Lafayette Rodrigues. Direito das coisas. 6. ed. Rio de Janeiro: Freitas Bastos, 1956.

PERLINGIERI, Pietro. O direito civil na legalidade constitucional. Tradução: Maria Cristina De Cicco. Rio de Janeiro: Renovar, 2008.

PERLINGIERI, Pietro. Perfis do direito civil: introdução ao direito civil constitucional. Tradução: Maria Cristina de Cicco. 3. ed. Rio de Janeiro: Renovar, 2002.

PUGLIATTI, Salvatore. La trascrizione: l'organizzazione e l'attuazione della pubblicità patrimoniale. In: CICU, Antonio; MESSINEO, Francesco (org.). Trattato di diritto civile e commerciale. Milano: Giuffrè, 1989. v. 14, t. 2.

RAMOS, Erasmo Marcos. A transmissão de propriedade no novo código civil brasileiro e no BGB alemão: um estudo comparado. Revista dos Tribunais, São Paulo, ano 92, n. 815, p. 38-76, set. 2003.

REALE, Miguel. Novo código civil: exposição de motivos e texto sancionado. 2. ed. Brasília: Senado Federal, 2005.

RENTERIA, Pablo. Penhor e autonomia privada. São Paulo: Atlas, 2016.

REZENDE, Astolpho. A posse e sua proteção. 2. ed. São Paulo: Lejus, 2000.

RODRIGUES, Marcelo. Tratado de registros públicos e direito notarial. 2. ed. São Paulo: Atlas, 2016.

SERPA LOPES, Miguel Maria de. Curso de direito civil. Rio de Janeiro: Freitas Bastos, 1995. v. 2. 
SILVA, Clóvis do Couto e. A obrigação como processo. Rio de Janeiro: Editora FGV, 2006.

TEPEDINO, Gustavo. Autonomia privada e obrigações reais. In: TEPEDINO, Gustavo. Relações obrigacionais e contratos. São Paulo: Revista dos Tribunais, 2012. (Coleção soluções práticas de direito: pareceres). v. 2. p. 43-66.

TEPEDINO, Gustavo. Multipropriedade imobiliária. São Paulo: Saraiva, 1993.

TEPEDINO, Gustavo. Normas constitucionais e direito civil na construção unitária do ordenamento. In: TEPEDINO, Gustavo. Temas de direito civil. Rio de Janeiro: Renovar, 2009. t. 3, p. 3-19.

TEPEDINO, Gustavo. Teoria dos bens e situações subjetivas reais: esboço de uma introdução. In: TEPEDINO, Gustavo. Temas de direito civil. Rio de Janeiro: Renovar, 2006. t. 2, p. 135-146.

TEPEDINO, Gustavo; BARBOZA, Heloisa Helena; MORAES, Maria Celina Bodin de. Código Civil interpretado conforme a Constituição da República. Rio de Janeiro: Renovar, 2011. v. 3.

TEPEDINO, Gustavo; FURTADO, Gabriel Rocha. Direitos reais coligados: uma investigação que se anuncia. In: COSTA, Ilton Garcia da; DIAS, Clara Angélica Gonçalves; FIUZA, César Augusto de Castro (coord.). Direito civil constitucional. Florianópolis: CONPEDI, 2015, v. 1, p. 143-162. Disponível em: http://conpedi.danilolr.info/publicacoes/c178h0tg/84k8hu2h/WWzX98aU7bQr3ri1.pdf. Acesso em: 01 ago. 2020.

TRIMARCHI, Pietro. Sulla responsabilità del terzo per pregiudizio al diritto di credito. Rivista de diritto civile, Padova, anno 29, parte prima, p. 217-236, 1983.

VANZELLA, Rafael Domingos Faiardo. 0 contrato e os direitos reais. São Paulo: Revista dos Tribunais, 2012.

VARELA, João de Matos Antunes. Das obrigações em geral. 10. ed. Coimbra: Almedina, 2000. v. 1.

VENOSA, Sílvio de Salvo. Direito civil: contratos em espécie. 4. ed. São Paulo: Atlas, 2004.

VENOSA, Sílvio de Salvo. Direito civil: direitos reais. 5. ed. São Paulo: Atlas, 2005.

VENOSA, Sílvio de Salvo. Direito civil: teoria geral das obrigações e teoria geral dos contratos. 4. ed. São Paulo: Atlas, 2004.

WALD, Arnoldo. A obra de Teixeira de Freitas e o direito latino-americano. Revista de informação legislativa, Brasília, v. 36, n. 144, p. 71-79, out./dez. 1999.

WALD, Arnoldo. Direito civil: direito das coisas. 12. ed. São Paulo: Saraiva, 2009. v. 4.

Recebido em: $13 / 06 / 2020$

Aprovado em: 12/07/2020 